How Do Nations Increase Workforce Skills? Factors Influencing the Success of the Singapore Skills Development System.

\author{
Sarosh Kuruvilla \\ and \\ Rodney Chua
}

Correspondence to: Professor Sarosh Kuruvilla

156 Ives Hall

Cornell University

Ithaca, NY 14853-3901

Acknowledgements: We thank Stephen Frenkel, George Boyer and Chistopher Erickson for comments on a previous version. 


\begin{abstract}
This paper contributes to the partial resolution of the debate regarding the role of governments in leading national upskilling efforts through a descriptive case study of the Singapore system of skills development. The paper identifies the major reasons behind Singapore's remarkable success in upgrading workforce skills in a relatively short period of 40 years. First, a general linkage between economic development needs and skill formation and development has been facilitated by an institutional structure that places the Economic Development Board at the center of the effort with responsibility for both areas. We argue that this general linkage is a necessary but insufficient condition for rapid skills upgradation. Second, the EDB's model of technology transfer, which over a period of time brought about the integration of three crucial aspects, i.e., linking foreign direct investment to skills development and joint government-private sector operation for skills training, was crucial in the ability of the economy to meet its short and medium term skills development needs. Third, educational reform for long term skills development and fourth, a levy/grant scheme (the Skills development Funds) that induced private sector firms to invest in upskilling were important contributors to the success of the system. Finally, the institutional linkages across various different skills development institutions and initiatives further ensured the effectiveness and relevance of upskilling programs i.e., the interconnectedness of the various parts of the system was a crucial element in the success of the Singapore effort. In sum, Singapore's system is consistent with the notion of a concerted national effort. Given that several nations have indicated their desire to copy selected aspects of the Singapore system (e.g., skills development funds) this paper cautions that it is important to understand that each component works because of the institutional context, and cannot be transplanted independently to a different institutional context and be expected to provide the same results.
\end{abstract}




\section{How Do Nations Increase Workforce Skills? Factors Influencing the Success of the Singapore Skills Development System.}

\section{Introduction}

Although there is agreement that most developing nations need to focus on skills development in order to meet the challenges in and from international markets, there is considerable disagreement regarding what strategies nations should follow to upgrade workforce skills. The question of skills upgradation is relevant for all types of economies, both developed and developing. For developed nations, as Streeck (1988) notes, high skills are the only route that advanced economies can sustain in the long run, given that their comparative advantage lies in their technological innovation and capabilities. For developing nations, the comparative advantage of low labor costs erodes rapidly, and the need to raise the technology and skill-intensity of their manufacturing sectors requires serious consideration of the skill upgradation question. For example, in Asia, the emergence of Indonesia, Vietnam, and China as new centers for low cost production have made it necessary for the NIC’s (S. Korea, Taiwan, Singapore, Hong Kong) to adopt a more technology intensive export oriented industrialization, for which skills up-gradation is critically necessary. As Koike (1996) has pointed out, the quality of human resource skills are critical for these countries to maintain their competitive position with the more technology intensive export orientation strategies they have adopted.

In addition, the need for developing workforce skills is rendered more acute given the increasingly wide wage differentials between skilled and unskilled workers, and that fact that much of the ranks of the unemployed consist of people who are unskilled or with low levels of skills. Further, both technological change and international trade in this era transform labor markets continually, changing the nature of jobs and the rate at which skills become obsolescent. Several authors have noted that the success of the NIC's is in part due to their human resource-led development strategies and that other nations wanting to change the basis of their comparative advantage from cheap labor or natural resources to technology and skill, should follow their example (Godfrey, 1997).

Despite work that has outlined the linkage between economic development and national human resource and labor policies (Kuruvilla, 1996), there is little agreement on 
just how nations can develop an effective strategy of upskilling. Much of the debate centers around the role of the government and its ability to raise workforce skills. Those arguing against a heavy government role highlight the inefficiency of government (markets are more efficient than governments in allocating resources for skill upgradation), and provide debatable empirical evidence on the failure of many government sponsored efforts in the advanced nations. Those in favor of government-led efforts talk about the many positive externalities of government -led skill development (e.g., the value of a well educated workforce), the need to get involved due to market failure (due to inadequate information, labor market rigidities, imperfect capital markets and other institutional factors), and to compensate for the inequalities imposed by markets (inequalities in the distribution of skills development opportunities). Pervasive empirical support for either perspective is absent, due to a number of data and measurement problems, hence the continuing debate.

This paper contributes to a partial resolution of this debate by examining one concrete and successful case of skills development, i.e. the case of Singapore, and drawing lessons from this case for other developing nations. Our methodology involved both archival research and interviews with knowledgeable "experts" in Singapore, and represents a tentative effort to identify why the system has proved successful in Singapore. We want to make it very clear that this is a descriptive paper. We do not have the data to conduct a full scale evaluation of the Singapore system (a focus of our future work) but we also recognize that we would have to devise a unique evaluation plan for a system that has so many interconnected components to it. In the following section, we (briefly) review relevant literature regarding skills development and international competitiveness, and the debate as to who should be responsible for skills development. Next, we discuss why Singapore is an appropriate case for this kind of inquiry, followed by our analysis of the factors that are important in the success of the important features of the Singapore's system.

\section{$\underline{\text { Relevant Literature }}$}

While it is not our purpose to review the considerable literature on the significance of skills development in a nation's competitiveness, we think a brief outline 
of the theoretical basis for this claim is necessary in providing a context to understand why Singapore is an appropriate case to study. A variety of theoretical perspectives have been offered as conceptual lenses to examine the nature, and process, of national skills development. In our review below, we focus primarily on the importance of skills in economic development, the process, and debates regarding who is responsible for national skills development.

The Importance of Skills in Economic Competitiveness

Both economic growth theories and trade theories have noted the importance of skills development in economic competitiveness. Behrman (1997) suggests that the New Neo-classical Growth Models" have renewed the interest in the aggregate relations between human resources and economic development. Several works are relevant here. Romer, (1986) for example develops a model whereby long run growth is driven by the accumulation of knowledge, and that the production of consumption goods as a function of the stock of knowledge has increasing returns, and the stock of knowledge may have an increasing marginal product in such use. This model implies a very important role for skills and HR in economic development, and that focusing on HR in terms of policy may have a social payoff because of both externalities and the increasing returns associated with HR investments.

Lucas (1988) builds on Solow's (1956) model by suggesting that the average level of human capital affects a workers productivity in addition to the effect of his or her own human capital, suggesting the need to invest in human capital economy-wide, while Azariades and Drazen (1991) argue that countries with higher human capital investments relative to their per capita income are more capable of sustained economic growth than others. Stokey (1991) suggests that human capital investments have a positive impact on the human capital of later cohorts so average human capital grows over time, and so does the quality of production. Thus, the implication of these studies are that investments in human capital are critical for economic growth.

Researchers linking human capital investments to foreign trade tend to use the standard Heckscher-Ohlin model. The general approach here is to view workforce skills and perhaps land as non tradeable factors of production and then examine the relative 
endowments of these factors to suggest the comparative advantage of manufacturing and primary products. Wood (1994) and Godfrey (1997) tend to use this approach.

Several authors, like Godfrey (1997) have focused on the process of transition of economies from low cost labor to skill intensive labor, and the arguments are also relevant for our study here. The central feature for example, in classical models of economic development by Lewis (1954) is that unlimited supplies of labor at the initial stage of economic development contribute to continued growth in the industrial sector. However the unlimited labor supply does not last as the industrial sector increases in size, and with real wages rising the labor supply curve slopes upwards. The assumption is that economies have to reach the stage of labor shortage before the transition to skill based competitiveness can occur. However, this transition is based on a number of other factors, notably a sustained growth in wage employment in manufacturing accompanied by productivity growth, a rise in the real product wage of unskilled labor and a narrowing of wage differentials between more or less qualified workers, and a supply of better educated labor in the senior secondary and tertiary sectors. And here, the quantity and the quality are necessary to make the transition to skill based competitiveness. Godfrey (1991) suggests that Indonesia has met this condition.

Another set of scholars link skills development to general levels of economic development not through trade, but through foreign investment. Both Koike (1996) and Kuruvilla (1996) suggest that investment in human resources generally and developing specific skills determines the amount and nature of foreign investment. Nations with abundant supplies of skills, other things equal will attract greater foreign investment generally, but will also attract the type of foreign investment that is targeted, for example, Singapore and Malaysia's success at attracting investment in the semiconductor sector depended to some extent on their ability to produce the skills that that sector needed (Kuruvilla 1996).

Despite the existence of such frameworks, the empirical support for these perspectives is less than persuasive, for a number of reasons. One exception is the report in the "East Asian Miracle Book" (World Bank 1993) which found that an increase of 10 percentage points in primary or secondary education would increase the rate of growth by $3 \%$. Otherwise, studies have demonstrated two major problems. The first 
problem is conceptual i.e, even if the theory tells us that human resources is important for economic development, there are enough examples of nations or regions within with poor economic performance despite high investments in skills (e.g., Philippines, Sri Lanka). Then in many cases, human resource development appears to follow economic development, rather than to lead it. The second problem is empirical, caused in large part by problems in measurement. For the most part, the empirical studies equate human resource development with education (since education is a convenient and handy measure). Yet, skills development is larger than basic education, as it involves training at different levels and within firms as well. Databases on skill levels and vocational training are not easily available nor systematically maintained in most developing nations. It is this problem of getting appropriate data that lead Godfrey (1997) and others to suggest that various studies that have suggested the importance of human resources in changing Korea's comparative advantage are purely speculative. Given that appropriate data is not available, this calls for different methods to address this problem, notably case studies of successful efforts in order to understand the process.

The Role of the government: What should Governments do?

The paucity of empirical work noted in respect of the relationship between skills development and economic growth is matched by the paucity of empirical work regarding the appropriate role of the government (but see Barro, 1997). The arguments however are more clear. There are those who argue that governments should not be involved in the skills development effort.

One argument is that governments are not successful or efficient at upgrading national skills, largely because markets are more efficient at allocating resources for skill development and upgrading (See a 1996 debate on this issue in the Economist, April 6, pp 19-21). Proponents of this view cite evidence, using diverse studies of Germany's dual education system, apprenticeship training in Britain, and studies of the job training partnership act in the US, to suggest that government-led efforts do not work. A second argument is based on Becker's (1967) work. Becker distinguishes between general and specific skills. General skills are the province of the employee and it is reasonable to expect that individuals would make an effort to invest in human capital to maximize their earnings and employment opportunities. Specific skills refers to those 
skills specific to each employer, that are generally not marketable outside, and thus, employers would provide these skills. The implication of this is there is little role for government in taking the lead in workforce skills development, beyond the necessary investment sin education.

Several arguments in favor of government involvement in skills development exist. One argument cites the positive externalities in skills development i.e., the value of a well educated work-force in general which helps the ability of a nation to adjust quickly due to changes in technology and markets, and these positive externalities will not result if left to the market. A second argument focuses on the various unrealistic assumptions of Becker's (1967) work i.e., there is no uncertainty as to the value of future returns to training, no limitations on the possibility of borrowing to finance one's own skills and no turnover of workers who receive specific training from employers. Given that none of these assumptions are satisfied in practice, the implication is that government should step in to improve the market (for general skills), through the provision of better information and the development of institutions to finance individual skills acquisition. A third argument focuses on the various other factors that cause market failure, such as inadequate information, labor market rigidities, imperfect capital markets , and a host of institutional factors, (e.g., short term financial markets, adversarial craft unions, weak employer organizations) that cause employers to adopt lower skill strategies than their rivals in other countries. A fourth argument for government involvement rests on the premise that a market led system will result in inequality in the distribution of skills development opportunities. In an attempt at reconciliation, Behrman (1997) basically suggests that the role of the government is to identify market failures and to considering whether they can be remedied by reasonable marginal social cost by improving markets or by other means. Thus, the only justification is that social returns must be higher than private returns. Proponents would suggest the use of active labor market policies such as those that operate in Scandinavia, but it is not clear that developing nations can afford to introduce those kinds of systems. And it is also not clear that such interventions would prevent market failure. Notably, the studies that have examined market failure have looked at vocational training (in countries of the West where reasonably good data exist on these issues), but this is not the same for developing nations. 
There is a small literature that has examined ways to improve government's intervention by comparing different models of government intervention. Edwards (1997) for example suggests that there are three models of government intervention. One is what he calls the state training model where governments both pays for and runs training centers for the industry, the second is the voluntarist model, where government provides the finance and employers provide the training, or levy/grant systems where the employer is taxed on payroll but gets the tax reimbursed if he actually gets involved in training.

Edwards does suggest however that the weakest model in developing countries (in terms of providing incentives for individual incentives for skill acquisition or corporate efforts at improving skills) is the state directed model. Its weaknesses include the fact that it is supply driven, poorly motivated students are trained in out of date skills and fail to get good job offers from employers, cost ineffectiveness of various programs, focus on training the unemployed as a political response to recessions poor management etc. The levy/grant system presents a way out of these problems, by forcing employers to invest in skills upgrading.

There is also some research that has made arguments about why some models of government intervention work. Edwards (1997) in reviewing several cases, suggests for example that the dual system in Germany works because of the general willingness (and ability) of companies to take a long term view, the presence of unions that are in favor of such systems, a high level of trust given the institutional context in which it operates and strong collective employer and employee organizations. The Japanese company training system works because it is buttressed by lifetime employment and low levels of interfirm mobility (by itself a major market imperfection) as a result of the peculiar characteristics of the Japanese system.

Singh (1990) offers a perspective that supports government intervention generally, but is also more prescriptive. Singh argues that for countries to remain competitive via upskilling, there must be a concerted national effort, and in particular, government and industry must join hands to tailor the country's education and training systems, amongst others things, to meet the skill needs elicited by new technology and the increasingly global economy. For Singh therefore, all the three models suggested by Edwards need to be used in conjunction for successful skills development. There have 
been no empirical studies as yet that support's Singh's perspective either.

What appears to be required are good case studies of success and failure. This paper aims at analyzing one highly successful effort at "upskilling” i.e. that of Singapore. Arguably, studying a concrete case of skill up-gradation inductively will yield valuable policy lessons for other developing nations, but also shed light on the as yet unresolved debate about skill up-gradation noted above.

\section{Singapore as an Example.}

Given the above perspectives, why is Singapore a good case to examine?

First, Singapore is probably the best known prototype of a nation that has successfully up-skilled its work-force over the last 40 years. For the fifth consecutive year, the World Economic Forum has rated Singapore's labor force first in terms of computer literacy, and second in the world in terms of availability of skilled people as well as worker motivation. The World Competitiveness Yearbook 1996 rated Singapore's education system first in terms of its ability to meet the "needs of a competitive economy". And the various executive opinion surveys reported in the World Competitiveness Report suggest that Singapore is ranked number 1 amongst all developing nations in terms of a number of human resource dimensions, including the availability of skilled people, equal opportunity, industrial disputes, worker motivation, attitude of the workforce, and competitive values. Finally, the biggest piece of international research on education standards (the Third International Maths and Science Study, 1997), which compared the scores of 13 year olds in math and science, placed Singapore at the top, in both math and science. (In comparison, the United States placed $17^{\text {th }}$ in science and $28^{\text {th }}$ in Math). On both education and training dimensions of national human resource development therefore, Singapore's achievements are excellent. The institutional features that account for such accolades is the subject of this paper.

In more specific terms, the number of people with tertiary level qualifications increased at an average annual rate of 10\% between 1983 and 1993. By 1997, almost all junior and middle level managerial and supervisory positions are held by local Singaporeans as are a significant proportion of executives and managerial ones, even in 
wholly owned subsidiaries of MNC's. For a more comprehensive listing of the evidence, see Cheah (1997). Between 1970 and 1991, human capital and technology intensive products rose from $14 \%$ to $54 \%$ of the total value of Singapore's exports. Most importantly, the annual average growth rates of graduates from post-school educational and training institutions over a the 1983-1993 period was high, as the following Table suggests.

Table 1: Average Annual Growth Rates of Graduates, 1983-1993.

$\begin{array}{lc}\text { Institutions } & \text { Average Annual Growth Rate } \\ \text { Universities } & 8.1 \\ \text { Polytechnics } & 10.1 \\ \text { ITE Courses } & 16.1 \\ \text { NPB Courses } & 14.7 \\ \text { SIM Courses } & 18.4 \\ \text { SIHRM Courses } & 24.2 \\ \text { ISS Courses } & 15.2 \\ \text { OSH Courses } & 34.0\end{array}$

Source: Cheah, 1997.

Second, there is some evidence that Singapore's efforts are consistent with some of the theoretical perspectives noted above, while in other ways it is remarkably inconsistent. Cheah (1997) notes that Singapore's experience is consistent with both the economic growth and trade theories. For instance, Singapore experienced rising wage costs, narrowing of skilled versus unskilled wage differentials, and labor shortages before it moved to a higher value added production system,, consistent with Godfrey's (1991) arguments. Singapore's experience appears consistent with the notions of a link between foreign investment and skills development highlighted by Koike (1996), while the Skills development Fund system is consistent with Edwards idea that levy/grant systems are the best model of government intervention. On the other hand, and consistent with Singh (1991), Singapore's effort was clearly led by the government, includes all of the various models noted by Edwards. Given the diversity of views, an analysis of the institutional features that make Singapore's model successful are clearly warranted. 
Third, one strong indicator of success is if other nations want to emulate. It is clear that that several other nations have attempted or are thinking of attempting to emulate the Singapore model. Malaysia, for example, has introduced some features of the Singapore model (Kuruvilla, 1996) while there is debate in India and several other countries regarding introducing the skills development fund system, the part of the Singapore model that has been most popular and most analyzed and described. Given the axiom in comparative industrial relations that specific institutions work in some countries because of the institutional setting in which they operate and will not deliver the same results when transplanted across nations with different institutional contexts, it would seem important to understand the institutional context behind Singapore’s successful effort. And, contrary to popular belief, the introduction of the levy/grant system is not the sole cause for success here.

\section{Method}

We want to make it clear that the purpose of this paper is to describe and identify the various factors that appear to be important in making the overall skills building system successful. However, at best, our conclusions can only be seen as tentative, given that we have relied on archival sources, and a few interviews with a non representative sample of government officers and executives (This is the first stage of our research project). Importantly, we do not have a direct measure of the effectiveness of Singapore's skills development policy, (it is not clear that measures of number s of people trained will capture the effectiveness). Instead, we take the effectiveness as a given, in view of the international accolades that Singapore has received, and survey data

used by the World Competitiveness forum that provides Singapore with the Number 1 ranking.

What we did was to examine government documents, interactions between different institutions in Singapore, and used the snowball sampling method of interviewing key officers of both government institutions as well as private sector firms and getting them to suggest the names of others who would be useful to talk to. This, what we present here is not the results of a systematic research project, but represents an effort to gain an initial understanding so that a more systematic research effort can be mounted. 
Further, given the length limitations for this journal, we do not focus on detailed descriptions of the Singapore system. Given the early stages of our research project, we do not make judgments regarding which factors are more important than others, nor have we designed a research procedure (at this stage) to answer the relative importance question. The Singapore story however suggests that a number of institutions and linkages across institutions play a key role.

\section{FACTORS CONTRIBUTING TO THE SUCCESS OF THE SINGAPOREAN SKILLS DEVELOPMENT SYSTEM.}

Our research project has identified a number of important issues in the Singapore system, and we discuss each separately below. The first factor is a rather basic one and is consistent with Kuruvilla's (1996) argument that there should be a close correspondence between national human resource policies and economic development policies. In what follows, it is our intention to briefly outline this correspondence vis-à-vis skills development and economic development. We view this correspondence (the integration of economic development policies and skills development) as a necessary condition for successful skills development, albeit not a sufficient one.

\section{The linkage between skills development and economic development.}

Singapore's skills development policies have been integrated with its economic development strategy, through a variety of institutional mechanisms. Thus, upskilling is a continuous and expanding process that is based on economic development needs. A key element facilitating this linkage is the institutional structure that places the Economic Development Board at the center of the effort in that it is responsible for both economic development as well as skills development (see Figures 1 and 2). This mechanism allows the linkage to be fairly tightly coupled. This is in sharp contrast to the experience of most developing nations, where the responsibility for economic development rests with the education ministry while responsibility for skills development rests with the Human resources ministry and with little interaction between the two.

We present an abbreviated discussion below of the phases of Singapore's economic development and the skills development initiatives associated with each 
economic development phase. More detailed descriptions of these initiatives can be found in Chua and Kuruvilla, 1997. Note further that the we focus only on skills development here although it is worth note that there is a correspondence between other industrial relations policies and economic development strategies as well.

Phase 1: Import Substitution Industrialization: 1959-1965

In 1959, Singapore's unemployment rate was $13.5 \%$ the population was poorly educated, poverty levels were high, and its traditional entrepot activities were in decline given the development of other trade routes to the West (Huff, 1994). Given its position as part of the Malayan federation, the economic development strategy adopted was one of import substitution industrialization based on labor intensive industries. During this period, three critical human resource development challenges were addressed.

The most critical human resource challenge was the need to create a more integrated education system to meet the goals of the import substitution industrialization, notes Soon (1993). Until this point, the colonial education system had emphasized the production of English speaking white collar workers for the bureaucracy, neglecting technical and vocational education. But ISI implied the need for trained industrial workers. And efforts at reforming education to meet industrial needs were fragmented and slow given the political uncertainty connected with the link with the Malaya federation.

The essential elements of the first five year plan for education included the building of new schools to promote universal access, increasing the emphasis on science, mathematics, and technical education, while highlighting the importance of bilingual education, with opportunities to follow education in English and all the three languages used by the population i.e., Malay, Mandarin, and Tamil (Soon (1993), and Chow, Phoon and Law, 1996).

The second challenge was to increase workforce skills in the general and technical area. The most significant initiative was the establishment of the Economic Development Board (1961). Although the board was established in order to design and implement an industrial policy, most of the boards' efforts during this period was to plan the development of infrastructure and facilities that would be necessary for industrialization. In particular, the board was charged with the responsibility of 
promoting foreign investment in Singapore (even during its ISI phase) given the lack of local capital and entrepreneurial ability to start ISI industries. As part of the development of infrastructure, training of workers and managers was a critical requirement. A series of secondary schools, commercial high schools and vocational institutions were established. In particular, the Singapore Polytechnic, and the Ngee Ann technical college (one public, the other private) were expanded and restructured to accommodate the new courses that were relevant to the industrialization needs at that time. (Vente and Chow, 1984).

A third challenge was the need for the development of management education, as Singapore did not have a corps of trained entrepreneurs. Management training was accomplished through the establishment of the Technical Constancy Unit and the Manpower development unit under the Economic Development Board. These two units operated in consultation with the fledgling Singapore Manufacturing Association, the existing universities and polytechnics and the adult education board, and provided management training until 1964, when this function was taken over by the Singapore Institute of Management.

Although the economy did not expand substantially during this period, the education reform was clearly successful. Primary school enrollment increased by $33.1 \%$ between 1960 and 1965 (Soon 1993). Secondary school enrollment increased by 93.7\% and university and college enrollments increased by $69 \%$. In addition, the technical and vocational institutes that were started in 1960 showed enrollments of 1200 workers by 1965.

Thus, this phase marked the beginnings of education reform, extension of vocational, technical and managerial education, and established the supremacy of the EDB as the prime mover of Singapore's industrialization strategy, and therefore also as the principal institution responsible for the coordination and supply of manpower to meet Singapore's manpower needs. As we shall see later, vesting the responsibility for provision of skilled manpower for economic development needs to the EDB proved useful later on. However, during this phase, the EDB focused only on the national level, and not on the industry or firm levels. 


\section{Phase 2: Export Oriented Industrialization: 1966-1973}

The loss of the large Malaya internal market resulting from the separation of Malaysia and Singapore in 1963, high levels of unemployment at about $10 \%$ as a result of the closure of the British naval base, and the negative impact the ISI strategy had on the balance of payments forced Singapore to adopt an export oriented industrialization strategy by August 1965 (Huff, 1994). The EOI strategy was predicated on attraction of foreign investment through a variety of incentives, and Singapore offered incentives, reasonably good infrastructure, and cheap labor and stable industrial relations climate as inducements to foreign companies. See Huff (1994) for a more detailed account of the nature and reasons for this shift.

The primary focus of skills development efforts was the urgent need for increases in technically trained manpower, both generally for the success of the of the EOI strategy, but also specifically to meet the needs of the emerging export industries, particularly in view of limited success of the previous five year plan regarding technical education. For example, only 6\% of secondary and junior high school graduates went for technical and vocational training. The government's approach was to expand vocational institutions (9 new institutions were established), start the Singapore Technical Institute to provide to train instructors to staff the technical and vocational institutes, through the Ministry of Education (Vente and Chow, 1984).

The EDB, focused on meeting the short term needs of the foreign investors (recall that the development strategy was predicated heavily foreign investment). The general approach was to request foreign governments, the UNDP, and foreign investors to fund and run training centers in specific skills and six centers in metal industries, prototype production, electromechanical industry, electrochemical industry, woodworking, and precision engineering and printing.

The welder crisis of 1970 (due to the rapid expansion of the ship repair industries and oil refining) further drove home to EDB the need for more investment in technical training. The EDB opened its Overseas Training Scheme in 1971 (OTS), whereby Singaporean workers were sent by the EDB at government expense to various countries to work in companies in countries that were the biggest investors in Singapore (Germany, Japan, and the USA) where they could be trained for this purpose. Trainees were required 
to sign a bond that they would work for the government for a minimum period of three to five years upon completion (Vente and Chow, 1984). The logical next step was to bring the kind of training that the OTS facilitated outside the country into the country, which the EDB achieved through the development of Joint Government Industrial Training Schemes (JGITS) during 1972-1975. Under this system, the EDB provided foreign companies like Tata (India), Rollei (Germany) and Phillips (Netherlands) the finance and infrastructure to set up training centers to which the companies would contribute instructors and software. These schemes served three important goals: the provision of training that was not available in Singapore, the establishment of regular contacts with foreign firms, and through these contacts, to induce foreign firms to invest in Singapore. This was the beginnings of the integration of skills and foreign investment and technology transfer. We will discuss the specifics of this emerging model of skills and technology transfer later in the paper.

These initiatives showed remarkable results. Within three years of the establishment of vocational training schools under the Industrial Training system, technical education enrollment had increased by a 1000\% (Vente and Chow, 1984). And, by 1975 about 800 people had completed OTS training. Thus, in this phase, we see the EDB begin a networking arrangement that not only enticed companies to invest in Singapore, but through joint arrangements, ensure that these companies participated in the training of the Singapore workforce so that they were ensured of a steady supply of skills, but the country would also benefit from the training in a more general way

\section{Phase 3: Evolution Towards Technology Intensive Export Oriented Industrialization:}

\section{$\underline{1973-1984}$}

As Huff (1994) suggests, the success of the export oriented industrialization strategy resulted in both a tighter labor market and rising wages. And increased competition from lower cost Asian neighbors such as Malaysia forced the EDB to reconceptualize its economic development strategy. A critical aspect was the need to continue to attract foreign investment, but to make sure that the foreign investment would be higher quality, i.e. more technologically intensive investment that would be able to use the higher cost Singapore labor. Thus, the shift contemplated was from labor intensive 
manufacturing for export to a more higher value added technology intensive industrialization for export. See Rodan (1989:119) for a more detailed description of this transition. This shift into more technology intensive higher skill based export orientation was accomplished through two major initiatives. One the one hand, the National Wages Council recommended double digit wage increases for three years thus successfully driving out lower cost producers. On the other hand, the government, via the EDB began to further restructure education and training in order to ensure that more higher skilled labor would be available for the higher technology based investment that was expected to come in. This investment was made possible by restructuring the incentive packages for foreign investors, and in particular giving special incentives to those investors who would set up research and development operations in Singapore (, Phoon, and Law 1996). And during this phase, Singapore’s approach to skills development and up-gradation intensified. The specifics are discussed below.

The critical need during this phase was for the continued expansion of general skills (vocational and technical training for industry in trades such as machining, fitters, electricians, welders) as well as the need for more specialized skills germane to the industries that were growing as a result of foreign investment. The primary initiatives during this phase were: the reorganization of the structure for technical and commercial skill formation, establishing foreign company and country sponsored training centers, reforming the educational system, and setting in place incentives to get corporations to invest in skills upgradation

Through a process of reorganization of several government agencies, the Vocational and Industrial Training Board ${ }^{1}$ was established in 1979 to spearhead training strategies. It functioned as the country's largest supplier of blue collar workers and technicians, as well as commercial, clerical and secretarial employees (Vente and Chow, 1984). Made up of 17 technical, vocational, and commercial training institutions, the range of its offerings are large (see Appendix 1), and it also manages the country’s Apprenticeship program (modeled on the German system). The Apprenticeship program, includes basic training at one of VITB's institutes and in plant training at companies (the apprenticeship contracts between companies and apprentices must be registered by the VITB, and there is close monitoring of training. The VITB also became the national 
authority for conducting examinations and certifying vocational and industrial training, and in this role has ensured a steady supply of trained technicians for the industry. For a detailed description of the VITB, see Vente and Chow, 1984).

Meanwhile, the EDB deepened its short term focus on the acquisition and generation of specific skills by building on the model developed earlier i.e., establishing foreign country sponsored training centers, and capped these initiatives with the establishment of the EDB's institutes of technology (for e.g., the German-Singapore Institute for Production Technology, The French-Singapore Institute (FSI) of ElectroTechnology and Japan-Singapore Institute of Software Technology (JSIST)

However, both the Ministry of Education and the EDB also began to take a more strategic perspective on long term skills development while scrambling to meet short term needs, given in particular, the rapid pace of economic development. The 1979 Ministry of Education report noted several problems with the education system, notably, the ineffectiveness of the bilingual system, the great variance in academic performance across schools that may cause potential skill imbalances in the future, low teacher morale, and wastage of educational resources. As a consequence, a new educational system was instituted (NES). In a later section this system is described in greater detail.

A final initiative during this phase was the effort of the EDB to shift some of the responsibility for upskilling onto the private sector. At the corporate level, the EDB tried to encourage companies to invest in training, through the (ITGS) Industrial Training Grant Scheme (the forerunner of the Skills Development Fund. All of the above initiatives are discussed in greater detail later in the paper.

In summary, during this phase of Singapore's economic development, it appears that the Government had finalized its strategy for the supply of general technical skills through the VITB, while the EDB had deepened the integration of technology transfer and skills training. Further, the basis for longer term development of skills through education reform and the apportioning of responsibility to the private sector for continuos skills upgradation through a levy/grant system.

While we discuss the EDB's approach and the private sector levy/grant system in greater detail, the evidence on the provision of general technical skills appear quite compelling. Survey results suggest that VITB training is generally considered to be good 
and that VITB trainees find employment more quickly and are better paid on average (Vente \& Chow, 1984). It offers a wide selection of full and part time courses, such that it gives full time workers an opportunity to upgrade skills. The part time courses offered are critical in view of the large numbers of older workers who are less skilled, and who have no option but to enhance their skills while working. Given Singapore's acute labor shortage, it is important for companies to retain these older workers as well as to ensure that they upgrade skills. Interviews with a Training manager at the Singapore Institute of Human Resources Management (SIHRM), and managers at various banks, suggest that this aspect of the VITB has been of great importance in the context of upgrading skills of older workers. It is also the only outlet for students who do not pass the secondary school satisfactorily and who have no access to college.

Phase IV: Economic Diversification: 1985 - 1996:- Consolidation and Restructuring of Skills Development.

By the mid 1980s, Singapore was already a leading high-technology, and high wage goods producer in Southeast Asia (Bercuson, 1995). And much of the preparatory work in terms of establishing continuous skills development had already been put in place during the last phase. The economic development goal of the EDB for the 1990s was to make Singapore a regional business and financial hub. On the business side, the focus was on attempting to project Singapore as the logical choice for the location of research and development centers of various multinationals for their ventures in the Asian region. And on the financial and services side, Singapore hoped to become the most important financial center in the region.

Consistent with this longer term vision, the EDB reconsidered its approach to skills generation. One key finding was that the depth and breadth of technical skills necessary for the accomplishment of this vision could not be achieved through the existing model of single country dominated institutions, like the GSI, or a single company dominated institution, like Phillips. In other words, the manpower needs of the new and emerging knowledge and technology intensive industries would require resources and expertise in excess of what a single partner could provide. And, as Soon (1993) notes, this would have to be accomplished without the proliferation of additional 
training institutions.

What emerged from these is a series of initiatives to organize technology centers that were centered around the needs of one industry, through joint cooperation with various multinational companies who had invested in Singapore. Several of the Training centers identified earlier (e.g., the German Singapore training center) were consolidated into institutions that served the entire industry, like the Precision Engineering Institute.

Second, there was increased integration across different institutions. For example, to give a further boost to apprenticeship training (under the VITB), the Skills Development Fund subsidizes up to $1 / 3$ of the apprentice training costs of the company, working in concert with the National Productivity Board ( NPB) launched the OJT 2000 plan in October 1993, and its goal is to train 700,000 apprentices by the year 2000. In addition, the ITE and the NPB are also responsible for the education and training of working adults (which includes people who did not complete junior or secondary school or who are unskilled). By 1991, there was a comprehensive system of continuing education and training making about 100,000 training places available to about 50,000 workers a year (Chow, Phoon, \& Law, 1996) Thus, this phase of Singapore's economic development saw a consolidation and reorganization of skills development.

Phase V: Towards a Knowledge based Economy

In the 1990s, the focus has been on the shift from factor driven growth to innovation driven growth, in other words, the shift from capital intensive industries to knowledge driven industries. The primary focus in this phase is an extensive push to increase corporate expenditure on training on the one hand, as well as devise alternatives for retraining the older workforce. The Productivity Services board has identified thirteen industrial clusters of industries for whom skills have to be developed. HRD is seen as the most essential investment to ensure continued economic growth in Singapore in this phase.

The way in which these goals are to be realized are still evolving, but already there is a massive promotion of OJT in companies through the Productivity and Services Board which has created a system of model OJT companies that are to be emulated by the rest. In general, the 
average investment of companies in training has increased in the last 10 years, from $1.8 \%$ of payroll to almost $4 \%$ of payroll. The Skills development fund, which itself has seen an increase in participation, also provides special financial assistance for the training of supervisers to deliver OJT.

In summary, the essential point that we wish to make in this section is fairly simple. What the discussion above shows is a fairly close correspondence or "fit" between the economic development needs and the skills development efforts, with a constant striving to meet industrial needs through quick short term solutions as well as some degree of long term planning. We think that this congruence is an essential prerequisite for the success of any skills development system, although not sufficient. By discussing these developments in some detail, we have provided a overview of the Singapore's efforts. In the next section, we discuss specific aspects in greater detail, notably the EDB's model of technology transfer and how it evolved into an integrated system linking foreign investment and skills development. We will also discuss other factors crucial to Singapore's success, i.e. the levy/grant system (skills development funds), and other related factors. 


\section{The EDB's Evolving Model of Technology Transfer, Foreign Investment, and}

\section{Skills Development.}

Perhaps the single most important factor in the success of Singapore's skills development system (and notably, the rapidity with which workforce skills were upgraded) was the EDB's model of technology transfer, which effectively linked skills development to foreign investment and private sector participation. This model, that evolved over a 10 year period, in our view, is far more significant than the introduction of the skills development funds, although the latter has received the bulk of academic attention.

The early development of the EDB's model commenced with the Overseas Training Scheme (OTS) described in Phase 2 of Singapore’s economic development. The purpose of the OTS was to have Singapore citizens trained abroad in companies that were large investors. Although the OTS was successful, it was more efficient if such training could be provided locally by the investing firms. Thus, the first step focused heavily on targeting individual MNC's and providing them with various inducements to invest as well as participate in the establishment of training centers.

The EDB here spearheaded the development of Joint Government Industrial Training schemes (JGITS) during 1972-1975. Under this system, the EDB provided foreign companies like Tata (India), Rollei (Germany) and Phillips (Netherlands) the finance and infrastructure to set up training centers to which the companies would contribute instructors and software. Each training center was managed by a Management Committee consisting of company representatives, EDB representatives, and representatives of the Vocational Industrial Training Board. The JGITS is modeled after the German apprenticeship system with two parts, i.e., the first part consists of a two year full time in center training on both theory and practical aspects of the trade, followed by a two year approved in plant attachment in any company designated by the management board. By 1984, the Tata Institute and the Rollei Institute had completed training for about 500 graduates each. And, numerous German companies offer the practical training 
portion for the Rollei Institute.

In order to get a better sense of the relationship between EDB and foreign investor partnership, we examined one of these centers, the Tata_Institute in a little more detail. In return for the Tata group’ contributions vis-à-vis training, the EDB granted loan finance to the TATA group in setting up their businesses in Singapore, reasonable industrial land rents, tax free remittances of technical fees, and various tax holidays (Soon 1993). For the center itself, the government provided land and buildings, paid for the purchase of the machinery and training equipment, and was responsible for $70 \%$ of the operating costs. The Tata Group was responsible for the provision of salaries to their instructors, and $30 \%$ of the operating costs. In addition, as part of the agreement, the center would train twice number of persons that were required by the TATA group for their own operations. From the supply side, each trainee was provided with a stipend, but was to sign a bond agreeing to serve the government (or any company as directed by the EDB).

The Rollei Training Center also functioned on similar lines. This center offered training in precision mechanics, precision optics, tool making and electro mechanics. And the EDB provided Rollei with several major incentives to invest in Singapore. For example, it granted Rollei the right of refusal for a period of 10 years, i.e,.., during this period, the wide range of products that Rollei would make was placed under a "Control of Manufacture Ordnance” which required all other potential manufacturers of the same products to seek a license to produce, which would be granted only if Rollei first refused or declined to manufacture these products in Singapore.

Apart from the generous incentives provided to these companies, the key element with respect to skills is the guarantee to these companies that they would have first claim on the graduates of the training programs that they helped run. For example, roughly $44 \%$ of graduates of the Rollei Institute were subsequently employed by Rollei and various German companies, while the rest found employment in other industries. The JGITS thus provided foreign quality training in Singapore at an affordable cost, without relocation of Singaporeans abroad, and most importantly, it provided skilled manpower that the industries needed currently, and ensured a steady supply of skills in the future. 
Faced with the rapid growth in foreign investment however during the 1970s, it was clear that focusing on individual companies alone would not be sufficient to provide the skills that the nation as a whole would need. Therefore, the EDB began to broaden its focus to deal with investor country governments. The logic was that if the government's of the investing countries got involved, more training could be conducted, but more importantly that would constitute a powerful signal to other companies in those countries that "Singapore was good place to invest".

For example, the Japan-Singapore Government Training Center (JSTC) was established largely because Singapore was deficient in key skill areas such as maintenance fitting, metal machining, electrical fitting, electronics instrumentation and mechanical areas, whereas Japan was a world leader in these. The JSTC was effectively used to promote Japanese investment notes Soon (1993), and served as an excellent public relations tool in attracting corporations in Japan. This center, along with the Rollei, Tata, and Phillips centers were turning out almost $60 \%$ of the skilled craftsmen required by 1978. The courses and curriculum at these centers served as models for the various vocational training institutes.

Accordingly, in 1979, this center was started, and managed on the same lines as the Tata, Rollei, and Phillips centers, and functioned in exactly similar ways. Thus, this center, in addition to the Tata, Philips, and Rollei centers, played a critical role in both upskilling and attraction of the right kind of investment. For instance, they speeded up industrial training such that these. Most importantly, the establishment of these centers virtually assured the EDB of additional foreign investment from these companies as well as countries, as they became more sure that they would gain control over obtaining skilled craftsmen for their industries (aided no doubt by the fact that trainees had to sign agreements that they would work for these companies or the EDB after training). Soon after the establishment of the Japanese training center, Germany and France also followed suit with centers of their own. The focus of these centers was the training of skilled craftsmen.

In order to ensure the supply of highly skilled technicians, (at the high end) to these companies, the EDB established its Institutes of Technology, based on the same model described above. These institutes were directed at training highly skilled 
supervisors and foreman, and junior engineers. Each such institute would maintain close contacts with technology leaders from the industry, and the courses offered at these institutes would be more intensive and have greater practical relevance. The trainees were given financial assistance in the form of stipends, loans, and bursaries, and required to sign a three to five year bond.

The first such institute was the German-Singapore Institute for Production Technology, which was proposed in 1978, but finally assumed operations in 1982 . The German government provided both financial and technical assistance as part of German Development Aid, while the Singapore government provided land, buildings and equipment. The GSI offered the following courses (Soon, 1993). Further, as of 1984, a total of 30 scholarships funded by the German Government has been offered to potential Singapore instructors to undergo training in Germany. Upon repatriation, these locals formed the core of instructors and training officers at the Institute (Vente \& Chow, 1984).

The French-Singapore Institute (FSI) of Electro-Technology was established jointly n 1983 by the EDB and the Ecole Superieure d'Ingenieurs en Electrotechnique et Electronique (ESIEE), a tertiary institute managed and operated by the French Chamber of Commerce and Industry. The agreement on this joint training institute reached with the French government is similar to the one reached for the GSI. Like the GSI, the FSI also requires that applicants have “A” Level qualifications, although since 1986, “O” Level holders are admitted on the condition that they complete an additional year of preparatory courses before they proceeding to the 2-year program (Soon, 1993). The trained technicians in the fields of electro-mechanical engineering, electrical engineering, electro-technology, and electronics with special emphasis on instrumentation, automation, industrial control, computer, and microprocessor applications. The primary reason for French willingness to establish this institute was the anticipated increase in French exports to Singapore, although from the EDB's perspective, this institute would also attract more investment from French firms, in the electronics sector (Vente and Chow, 1984).

The Japan-Singapore Institute of Software Technology (JSIST) started operations in 1982. This was consistent with the EDB's plan to develop a sophisticated export-oriented computer industry, and was also in anticipation of the rapid growth of the 
computer software and services industry. Most significantly, it complemented the tremendous growth in electronics hardware industry in Singapore. Although financed by the Japanese government, Japanese computer companies, are responsible for supplying the instructors for the school since they are the experts in computer business applications. This was the first time that Japan had launched joint government(Japan)-Industry(Japan) efforts to promote the export of Japanese computers to Southeast Asia (Vente \& Chow, 1984). The main functions of the institute include: 1) The training of high-ranking officials from the private and public sectors in computer technology, and in particular, the training of software personnel; and 2) The provision of more advanced training for computer scientists, systems analysts, and computer programmers in Singapore (Vente \& Chow, 1984)

The Japan-Singapore Technical Institute (JSTI) was the earlier discussed JapanSingapore Training Center (JSTC) that was upgraded to a technical institute in 1983. The JSTI now specializes in training skilled technicians in handling automated machines including industrial robots, Computer Numerical Control (CNC) machines, pneumatic and microprocessor-controlled equipment (Soon, 1993).

Thus, the EDB created a system of training and upskilling that ensured supply of skilled craftsmen and skilled supervisors and technical people to the foreign investors. And although the number of trained people from the EDB's institutes were small in number compared to the polytechnics, that small number constitute a critical course of skilled workforce which has played an instrumental role in Singapore’s economic development (Vente and Chow, 1984). While these practices provided skilled manpower for the present requirements, the EDB also began to take a more strategic view of longer term skills development given the maturity of its EOI strategy and the need for a more diversified industrial strategy (Kuruvilla, 1996).

Given the diversified strategy (Huff 1994) the EDB reconsidered its approach to skills generation. One key finding was that the depth and breadth of technical skills necessary for the accomplishment of this vision could not be achieved through the existing model of a single country dominated institutions, like the GSI, or a single company dominated institution, like Phillips. In other words, the manpower needs of the new and emerging knowledge and technology intensive industries would require 
resources and expertise in excess of what a single partner could provide. And, as Soon (1993) notes, this would have to be accomplished without the proliferation of additional training institutions. The EDB’s “transnational” approach was to secure MNC cooperation to participate in joining training programs within the existing institutions. Thus the EDB's model, which was based on single foreign partner for each training institute was expanded into a multinational partnership centered around relevant industries. One of the best examples of this effort has been the transformation of the Rollei center into the Precision Engineering Institute.

After the collapse of Rollei-Werke, Braunschweig, the Swiss MNC Brown-Boveri (Now Asea-Brown Boveri) took over the foreign partner role in the Rollei Institiute (it became the Brown Boveri-Government Training Center (BBGTC) in 1982), and with the adoption of the multi-partner model, became the Precision Engineering Institute (PEI) in October 1988. The Tata-Government Training Center (TGTC) was absorbed into the PEI. This was soon followed by several firms participating in co-operation projects within the PEI in specific application technologies. These institutions are managed on the following lines.

- EDB's instructors and technical staff are to be trained in the participating firms overseas locations.

- All participants are to assist in the training curriculum and its development.

- All participants are to provide and upgrade the equipment and software used for training.

- All participants must commit for a minimum of three years. Some examples of centers within the PEI included:

- $\quad$ Siemen-Nixdorf-EDB Center for Advanced Tool \& Die Making

- Mitutoyo-EDB Metrology Laboratory

- Japan-EDB Computer Numerical Control Laboratory

- Ikegai-EDB Computer Numerical Control Laboratory

- Bridgeport-EDB Computer Numerical Control Laboratory

- Sodick-EDB Computer Numerical Control Laboratory

- Autodesk-PEI Computer Aided Design/Computer Aided Manufacturing Unit 
A perhaps even more significant example has been the transformation of the GSI (German Singapore Institute) into a fully computer industry oriented training center, but also facilitating technology transfer into Singapore by putting together the skills of various Japanese, European, and US companies into one place. For example, the EDB has successfully gotten agreement from several MNC's for its key training institution in the computing sector, i.e., the German Singapore Institute. Thus, Japanese companies such as Seiko, Japax, Sankyo Deiki, Matsushita and Mitutyo contribute their equipment, knowledge, and training in the areas of Surface Mount Technology, IC design, Computer Numerical Control Technology, Manufacturing Resource Planning, and control engineering. European companies such as Siemens, Bull, Asea, Telemechanique and Carl Zeiss contribute their equipment and skills in the areas of artificial intelligence, laser technology, and vision technology, while American Firms such as Hewlett Packard, Autodesk, Mentor-Graphics provide equipment and expertise to train people in CAD/CAM, robotics, and simulation software.

By establishing several transnational partnership within the same institution, each partner firm was able to use not only the equipment and facilities of the EDB's training institutions, but also the equipment and facilities of the other transnational partners. From the EDB's perspectives, this arrangement would enable them to overcome the obstacles in any high technology training program, namely, the high costs of equipment, the lack of training expertise, and dealing with rapid obsolescence. Most importantly, though, this arrangement permits the EDB to acquire the necessary hardware, software, and teachware for the establishment and development of knowledge and technology intensive industries in Singapore. With the success of these efforts, several centers focused on different industries have been established. These larger transnational projects, referred to as specialized training units and laboratories, enable EDB to undertake specialized training and continual upgrading training (CUT). (Soon, 1993).

This model of technology transfer integrated with the attraction of foreign investment has been of pivotal importance in the generation of needed skills for foreign investors, but has also resulted in the upgradation of skills economy-wide, through the training of instructors for the various other vocational training centers in Singapore 
(Soon, 1993). It is our view that the EDB's technology transfer model has played a more central role than any other initiative in shaping the skills development scenario in Singapore.

\section{Skills Development Fund.}

No discussion of the Singapore system will be complete without a discussion of the Skills development fund, largely because it is this institution that has been touted as a model for other countries. However, it is only one small part of a much larger process, and a part whose overall effectiveness is difficult to evaluate. The essential element of the SDF system is that it represents the Government's efforts to pass on responsibility for skills upgradation to the private sector. The government-private sector partnerships established by the EDB implicitly in its model of technology transfer was limited to MNC's but the SDF was targeted towards all Singapore businesses. Given the need to upgrade skills quickly, consequent to the adoption of a higher EOI strategy in Phase 3, spurred to some extent by the increased wage costs and labor shortages, the EDB convinced the government that legislatively backed scheme was required (Earlier, the EDB had introduced the ITS, the industrial training grant scheme that provided firms with EDB grants to upgrade skills, but the limited use of such grants and the costs involved convinced the EDB of a nationally applicable legislated effort). The Skills Development Fund System was established in 1984.

Employers are required to contribute 1\% of gross salary of each employee earning below 1000 Singapore dollars per month (this would cover most blue and white collar workers) into the Skills Development Fund. Companies can get the value of their contributions back, or upto $80 \%$ of their contributions back, if they apply to the SDF for grants for training and skills enhancement. Companies could apply for grants to train workers, to buy more modern equipment, to expand or establish training facilities, or for overseas training. It also is a way to induce companies to continuously invest in skills upgradation, and it penalizes companies who persist in using low skilled workers in low value added operations by increasing their labor costs. The specific nature of the grants vary however. The rules include the following: Employers who submit a "Total Training Plan” affecting at least 50\% of their workforce would be awarded with higher grants and 
subsidies from the SDF; Employers who provide workers with training in skills that are, or will be, in high demand would receive twice the usual training grant; Grants are typically awarded to companies who would use it to fund training programs necessary to enhance the expertise of the workers concerned;. The skills to be acquired must be of a high degree of specialization, complex in nature, or require a long period of training; The objective of the training program must be consistent with Singapore's new economic strategy and direction; Special incentives are provided for companies to train older workers aged 40 and above.

The EDB and the Government has been able to incorporate specific targets and programs to meet specific needs through the SDF. For example in recent years, SDF focuses heavily on providing funds for training in the strategic clusters of industries and in 1996, the clusters that were targeted included robotics, product/ systems design, factory automation, and precision engineering for the manufacturing sector, and for the service sector, training in logistics management, advanced programming, and conference management. It is also important to note that the specific nature of the schemes and initiatives that SDF either has started, or provided finance for, are varied, including programs to enable women to get back to the workforce, programs for older workers, basic education. The introduction of the SkillsNet system, (a national training computer network that enables companies to submit applications for training grants electronically has eliminated processing time of applications for training subsidies from 7 weeks to three weeks.

And in order to encourage use the SDF, National Training Awards were instituted, which recognized companies who are committed to workforce training as determined by satisfying nationally established training criteria for a particular year. The SDF is managed by the EDB and a tripartite advisory council, formed by representatives from the government, industry, and trade unions. The council establishes the guidelines for SDF application approvals, formulates the terms and conditions for grants and loans, determines the amount of financial assistance to be awarded to the applicants and handles appeals from rejected applicants.

Corporations have reacted positively. A 1990 National Productivity Board (NPB) survey showed that $29 \%$ of the workforce had undergone training and that companies on 
average spent about $2.4 \%$ of their payroll on training. An evaluation of the SDF's operations in 1996 suggests that through the SDF system, about one person out of every three Singapore employees will have training every year (an astounding 33\% of the workforce undergoing skill upgradation annually) (Annual Report 1996, SDF). On average, training expenses in companies have increased from 1\% of payroll in 1986 to 3.6\% of payroll in 1996. In particular, it is worth note that the SDF has increased significantly the participation of small and medium size companies.

The SDF's strengths are that it is managed by the EDB, (which could structure grants to meet economic development needs), the fact that it uses both a carrot and stick approach, that it is advised by the tripartite actors (guaranteeing that all three actors are committed to the concept) and is flexible in terms of the kind of training programs that it funds (based on national or corporate needs. An important indicator of success of the SDF system is the link between training and productivity. In the manufacturing sector, the industries that were the biggest investors in training (as per SDF figures) are also the most productive. For example, in the computer disk drive and peripherals industry, (the most intensive user of the SDF) the value added per workers exceeds 138000 dollars, which is twice the manufacturing average. This industry alone accounted for over $30 \%$ of the training places in 1995. In the service sector, companies in the transport and communications industry accounted for $24 \%$ of the training places in 1995 , and the value added in this sector was 96000 dollars per workers, about one and a half times the average of the service sector (Annual Report, SDF). It is expected expect that by the end of the century, companies would be spending about $4 \%$ of their payrolls on training (note that the SFD requires a contribution of $1 \%$ only) and that $50 \%$ of the workforce would undergo 35 hours of training each year.

The SDF conforms to the classic levy/grant system suggested by Edwards (1997). Several countries have had variants of this system. Malaysia has the same system, while Korea had adopted a tax incentive for Companies to invest in training. In depth evaluations of this system have not been conducted, although the available evidence suggests that the system is responsible for the fact that corporations spend $3.6 \%$ of their payroll for skills upgradation. The success of the system, however, should be seen in the larger institutional context and the EDB's model of technology transfer. 


\section{Long Term Skills Development: Education Policy}

The above mentioned efforts focus on the creation of specific skills to meet immediate and medium term needs. However, successful skills development requires long term investments in education as well, given the considerable research on the impact of education in economic growth. In Singapore there have been two major reforms of education policy. The first was during the beginnings of import substitution industrialization soon after independence (discussed earlier) and the second was during the transition from low cost EOI to advanced EOI.

The move towards a more technology intensive export orientation coupled with the initiatives for training forced the government to rethink its education system, in particular to recheck whether the education policy planned in the 1960s was still relevant, given the rapid development since 1960s. The 1979 Education Ministry's report written by the Minister of Education Dr Goh Keng Swee, noted several problems in the Singapore education system, notably, that the bilingual policy was ineffective, there was a great variance in academic performance across schools, potentially causing future skill imbalances, low teacher morale, and a large amount of wastage of educational resources. As a consequence of this report, a new educational system (NES) was instituted, on the following lines.

The traditional or formal education system consists of 1 year of pre-school education, six years of primary school education. During the primary education, the focus would be to provide students with a solid grounding in mathematics and languages (33\% of teaching time devoted to mathematics, 20\% to English and the mother tongue of each child, and the balance time left for other subjects). In addition after Primary grade 4, based on their performance and potential, students would be divided into three major streams, the normal bilingual (English and mother tongue as the primary language of instruction), the extended bilingual (English as the primary language, mother tongue as the secondary language), and the monolingual (English, with mother tongue at oral proficiency levels only) streams. And parents participate to decide which is the appropriate stream.

At the end of six years of primary education, students would have to pass a nation 
wide primary school leaving certificate examination (PSLE) to proceed to secondary school, and this exam tests them in English, mother tongue, math and science. Students who failed would continue to finish 10 years or education before going on to various work related trainee schemes. Secondary education, (also free) consists generally of four or five years of education (depending on one's performance) and after two years in secondary school, based on student performance, students are channeled into science, arts, commerce, or technical stream. At the end of the secondary education, students must pass the Singapore Cambridge General Certificate of Education (GCE “O” levels), an exam which is conducted throughout the British commonwealth. After "O" levels, the student then goes on to Junior college for two years before entering the university.

The rationale underlying this NES was as follows: For one, it would introduce a great deal of flexibility, in that the system was designed to accommodate students at different paces of learning, as well as providing them with different options in terms of focusing on their bilingual education. The common examinations on the other hand ensured a consistent standard. And finally, the part of the education system that channelizes students into vocational courses if they do not show an affinity towards more academic work ensures like the German system, that there is a continuous stream of persons entering the industry after vocational or apprenticeship training. In addition, the streaming in the middle of the secondary school year into different disciplines and the prestige accorded to those who managed entry into the science stream would also ensure that the technical workforce that Singapore was seeking would be met. However, the strict nature of streaming has been criticized, since students are streamed into different language based instruction very early, and also are streamed into science, arts, or commerce, or technical streams before they are 13 years of age. This system (notes Pang Eng Fong1982) forces students to choose areas of specialization according to early academic performance rather than their natural inclinations so people who decide late get shot out of the system.

Along with education reform at the school level, there was also reform in the curriculum at the college level, particularly in engineering at the two major universities, the National University of Singapore and the Nanyang Technological University. Notably, there was also an increase in funding for expansion of these two universities. In 
addition four polytechnics have also received increased funding for expansion. See Soon et al for a detailed description of these. In addition, a fifth polytechnic (the Commercial and Service Polytechnic _ was established in 1984 to conduct studies and to prepare trainees for careers in the hotel trade and tourism, design, and computer sciences (Vente \& Chow, 1984).

In the 1990s, there has been need to rethink education policy issues again. One major criticism is that this need based and specific form of education and training for economic development needs has arguably turned out a lot of people who cannot think creatively, and thus broad and general education is suffering at the expense of specific job related skills training. Despite the World Competitiveness yearbooks ranking of number 1 in terms of the ability of the education system to meet the needs of a competitive economy, the Ministry of education's own survey with employers to get feedback about its graduates provide a startlingly different picture. The survey found that graduates are competent, but lack creativity. They have good analytical abilities and are able to reason logically, but they are not strong on innovative or creative thinking and in dealing with problems that are not well defined. This is largely because of a focus on seeking good grades in examinations. This criticism echoes the criticism of American MBA students by companies who have begun to recruit liberal arts graduates in order to get better creative thinking individuals rather than the highly narrow focus of the MBA curriculum in the1990s.

The lack of ability to think creatively, it is argued inhibits future development in that the system is producing employees, and not entrepreneurs. The primary criticism is that students “ do not question the given” at all. Although some have defended this on the basis of culture, ("we are more reticent, so the thoughts and ideas do not get expressed”, complaints from corporations and feedback from Ministry of Education surveys suggests that there is indeed some basis for this criticism. However, this criticism is not necessarily shared by all. For instance, Hewlett Packard has less problems with the quality of Singapore engineers (the mobile ink jet printer was designed and developed here in HP's research and development operations) but they appear to have problems with the quantity. Hence, they are forced to recruit from outside.

Notwithstanding the different views on quality, the Prime Minister, in September 
1996, launched the Thinking Skills Program, to encourage better thinking in the schools. The objectives of the thinking skills program is to improve creativity and lateral thinking. Although there is agreement that there must be fundamental change in the education system at all levels to meet these objectives, the first steps are to develop open ended examination questions to test students ability to innovate and not just regurgitate information. In addition, the National University of Singapore has started a program where students will be expected to prepare papers and defend their views, as well as open book examinations, so that memorizing will not be the primary route to success at examinations.

A second reason to focus again on education reform centers around Singapore's longer term economic goal of becoming a regional research and development center. Based on forecasts that identified a severe shortage of scientists and engineers, the government recently announced a 2.8 billion UAS dollar plan to boost the pool of research scientists from 7900 in 1986 to 13000 by the year 2000. This demand will be met by a combination of immigration, as well as increasing local output. One strategy to increase local output has been to increase the number of females who take engineering classes, and at Nanyang Tech, female enrollment in engineering courses have increased from $15 \%$ to $23 \%$ in the last year (FEER November $14^{\text {th }}, 1996$ ).

\section{A Concerted National Effort Through a Web of Institutions.}

We have discussed the major features of the skills development system in Singapore. However a crucial ingredient in the success of the system is the way in which these institutions work in practice. Clearly there is a concerted national effort here occurring at different levels in the nation. Many features of the system indicate the national and concerted effort. First, the system operates at several different levels, including education systems, training for managers, training for high-level technical skills, training for lower level technician skills, training for blue collar workers and older workers, and training for productivity improvement. It thus covers a wide spectrum. Second, it is done by both the government and the private sector, through a system of partnerships. The joint programs with the private sector are both numerous and diverse, including industry based centers such as the oil industry, firm based centers, jointly 
government-private sector institutes. Third, the different government institutions such as the ITE and the NPB work in tandem to provide courses, despite being different government departments. Thus, a network or web of institutions that work together is established. Fourth, there is input from different actors in the country at most levels. All the government run institutions are managed by a tripartite board with representatives of government, management, and labor, while the joint Singapore-Foreign government institutions have similar tripartite advisory committees. In this way the critical actors in industry have a voice in terms of the objectives and methods of skill training.

A pictorial representation of the institutional web in Singapore is provided in Figures 1-5.

Insert Figures 1-5 about here.

As these figures suggest, not only is the web of institutions fairly complex and developed, but there is constant exchange of information across different organizations. These charts do not purport to be an indication of organizational structure, but more an indication of where the different institutions are located. Figure 1 shows the institutions at the primary level. The black lines indicate reporting relationships, while the broken lines indicate instances where there is coordination and communication between the parties. It is important to note that these broken lines hide a lot of institutional cooperation. For example the cooperation between the EDB and the NPB is quite complex, as they have jointly designed a number of the training programs run by the NPB listed in the Appendix. The red lines suggest the areas where there is tripartite input, either through tripartite representation on the boards of the institutions or tripartite advisory councils.

Figure 2 shows a sub section of Figure 1 in that it focuses solely on the Economic Development Board and its related institutions. Note that linkages with other institutions are not represented in this figure. Figure 3 then focuses on the Institute of Technical Education and its affiliated institutions, while Figure 4 depicts the National Productivity Board and its institutions and programs. Figure 5 shows broadly the education establishment in Singapore, while Figure 6 lists the various industry training activities, but does not show the reporting relationships or linkages with other institutions, largely because many of these are free standing programs.

In particular, this web of institutions has been managed through frequent 
consolidations and reorganizations to maximize effectiveness, and has facilitated a rapid diffusion of skills development, while at the same time maintaining the relevance the effort. We provide some examples of these aspects below.

\section{Consolidation for Effectiveness and Diffusion}

The government has continually reshaped institutions to maximize effectiveness. For example, given the vast growth in the skills development and vocational training institutions over the 1973-1984_period, there was some need for restructuring and coordination. The Council for Professional and Technical Education (CPTE), created and chaired by the Minister for Trade and Industry was established in 1979. Its function is to coordinate training conducted by the universities, the polytechnics, and the technical institutions of the EDB and the VITB to match the economic challenges (Chow, Phoon, \& Law, 1996). CPTE is invested with the responsibility of ensuring that the pool of trained people would be adequate, and for recommending to universities, polytechnics, vocational institutes, and EDB's training institutions, enrollment targets, staffing, and financial requirements for their different departments. These targets are consistent with the current and potential future demand in the labor market (Soon, 1993).

Once the multinational partnerships were established, the EDB stepped in again to consolidate its higher level skills program through the establishment of Applied Technology Group (ATG) in 1985. The primary function of this group is to manage the various different larger transnational projects that the EDB has entered into. These larger transnational projects, referred to as specialized training units and laboratories, enable EDB to undertake specialized training and continual upgrading training (CUT). (Soon (1993). Besides serving as showcases of application technologies, the ATG has been able to use them to offer specialist manpower development programs and up to date CUT programs. These programs include training of a vast array of people, including IC design Engineers, automation engineers, tool and die designers, surface mount technicians, and advanced craftsmen, at various levels, including post graduate levels.

Further, the VITB discussed earlier was reorganized and upgraded to the status of a post secondary institution, called the Institute for Technical Education (ITE), formally established on April 1, 1992. The ITE is a union of the Industrial Training Board (ITB), the Adult Education Board (AEB), and the Vocational \& Industrial Training Board 
(VITB). Its new mission includes the need to function as a post-secondary training institution providing and regulating industrial training and development (e.g., regulating and developing certifications and standards for technical skills), provide secondary school leavers with higher level skills training, wider career options, and a potential second chance to pursue a polytechnic or a university track, to promote, regulate, and intensify industry-based training in technical skills (e.g., apprenticeship and On-the-Job Training OJT), to increase training rigor and to give it a greater practical bias, and to serve as a consultant on technical training, and also to do research in this area.

The process of consolidation also enhanced the diffusion of skills development. In every case the different centers jointly established with different companies or governments were ultimately taken over by the Government or the EDB. For example, the German Printing School established in Phase 2 was later absorbed into the Baharuddin Vocational Institute. The Rollei and other institutes was taken over to form the PEI. In April 1987, for example, the JSIST came under the control of the Singapore Polytechnic. By this process the government acquired ownership of the curriculum and ensured its wide-spread diffusion throughout the web of training and skills development institutions.

The consolidation in some areas resulted in more integration both through the reshaping of old institutions as well as joint collaboration across institutions. One example can be seen in the role of the National Productivity Board. The National productivity board although established in1973 as a department under the EDB has now been made independent. The NPB's purpose is to facilitate the improvement of productivity across all sectors and industries, which it does through the provision of specialized training programs that are focused on productivity improvement. The NPB also plays a key role in ensuring that the impetus for training is maintained, and that it is affordable and available to all. The NPB role is quite critical, since in the name of increasing national productivity, its focus and programs cuts across industries, sectors, and age groups in the economy.

In another example of collaboration, to give a further boost to apprenticeship training, the SDF and the NPB jointly launched the OJT 2000 plan in 1993, with the objective of training 70,000 apprentices by the year 2000. To spur this effort, the SDF 
subsidizes up to $1 / 3$ of the apprentice training costs of the company. Another example related to the ITE and NPB have jointly created a comprehensive system of continuing education for working adults (people who did not complete junior or secondary school or who are unskilled), and by 1992 they had put in place a comprehensive system of continuing education and training making about 100,000 training places available to about 50,000 workers a year (Chow, Phoon, \& Law, 1996).

In addition, the relevance of skills development is maintained through the various feedback loops. Each institution has ties with the real world in terms of getting information and advice as to what kind of training is necessary so there is continuous feedback. For example, in terms of ITE, there are Trade Advisory Committees comprised of tripartite members, and in terms of the Skills Development Funds, there are tripartite advisory councils. In other areas, particularly in the area of specialized skills, relevance is maintained because various EDB sponsored skill upgradation programs are in reaction to the felt needs of the industry, or are relevant because the provision of these skills is critical to the successful attraction of foreign investment. Given that most of the institutes of technology and engineering are jointly managed by the EDB or appropriate government and the foreign investor, and where the investing companies have the first choice of trainees, maintaining relevance is highly necessary. The relevance of programs is also evident in the large numbers of programs created for special needs (see Appendix 2) and the continuing restructuring of existing institutions to make the delivery of skills timely.

\section{Conclusions}

In this paper, we have attempted to describe the major elements in the skills development system of Singapore. We find that the several features contribute to its success, notably the general integration of skills development and economic development achieved by making the EDB responsible for both activities, the EDB's evolving model of technology transfer that has effectively linked skills development with foreign investment and joint government-private sector management of training to ensure the

development of appropriate skills. These efforts are supported by education reform and 
skills development funds that induce each employer to invest in upgrading skills, in a context where different institutions work in collaboration to meet skills development goals.

In many ways, the Singapore example provides very strong support for the notion that government's do have a significant role to play in skills development. The type of government clearly matters though, and Singapore's government has been noted for its technocratic approach However, the case suggests that apart from the type of government institutions, the method by which the system is implemented also matters. Perhaps the most significant institutional detail is the fact that the responsibility for economic development and skills development rests with the same authority i.e., the EDB, and that there is significant private sector involvement and partnership with government in skill formation and development. Given the breadth and depth of Singapore's approach, it would seem to be a good example of what Singh (1990) terms a national and concerted effort.

\section{Sustainability and Transferability Issues}

Is the skills development system in Singapore capable of addressing the challenges that lie ahead? The vision for the future is one in which Singapore is a knowledge based economy, a regional research and development center, and a nation of entrepreneurs. The government has been very clear that it needs to ramp up its production of research and scientific people, and although large amounts of money is earmarked for such efforts, there is agreement that in the near term, these needs will be met by immigration. More important perhaps is the problem that of a lack of creativity and critical thinking that has been identified by many foreign investors and recognized by the Government. The argument is that Singapore has turned out competent people who follow orders well but are not creative.

The government last year launched the CRESP program, focusing on the expansion of critical skills throughout the high school experience and is retooling curriculum and exams to get future students to be more creative. They have sent a study team to Silicon valley to understand better the creativity required in running a knowledge 
based economy. However, Silicon valley is a very informal setting with a culture that practically encourages failure or at least, does not penalize attempts at creativity that are not successful. Singapore, on the other hand is a more regimented system where the government is the primary player and is unforgiving about mistakes. Clearly, it is not possible to "manage" creativity of the sort found in Silicon valley, and to replicate those conditions in Singapore would require the recognition that a large number of political, social, and economic factors are responsible for the creativity in the USA, and also that engendering such creativity is a long run tendency, not a short term problem. Therefore, the key question regarding the future sustainability of the Singapore skills development system is whether they can make the transition to meet the next challenges smoothly enough .

Transferability Issues

To what extent is the Singapore system transferable to other nations. We must recognize of course that there are several facilitating conditions that make the system successful in Singapore's context. First, industrialization in Singapore has been fairly narrowly focused, on a relatively small number of industries, mostly in electronics. With such a small breadth of industry, it is relatively easier to ensure the supply of adequate skills for these industries and the backward and forward linkages that these industries have generated. Second, the performance oriented culture of Singapore's government (legitimacy drawn to a considerable extent from national economic performance), coupled with the technocratic nature of the government bureaucracy has certainly helped in the design and delivery of skill formation mechanisms. (In a recent book Schein, (1996) documents the nature of organizational culture at Singapore's Economic Development Board, noting its strategic pragmatic focus). Besides, we must also remember that Singapore's rapid growth has been under conditions of labor shortage as well, which provides its added incentive for rapid upskilling, unlike in labor surplus countries such as the Philippines and India, where the urgency does not exist. Fourth, the government is the main driver of economic activity in a capitalist country, a unique situation. Fifth, Singapore has relatively small informal sectors and no rural sector. Sixth, the tripartite system in Singapore is unique in Asia. For these reasons, one might argue 
that the Singapore system is a case of "Singapore exceptionalism".

What are the lessons for other developing nations from this experience?. Already several countries have shown interest in introducing the skills development funds system given its apparent success in Singapore. Our study would imply that such transplanting of successful institutions is fraught with danger. It is an increasingly accepted axiom in industrial relations that attempts at transplanting successful systems from one country to another without taking into account the context in which that system operates is bound to result in failure (Katz, Kuruvilla, and Turner, 1994). Kuruvilla (1997) and Hiers and Arudsothy (1999) suggest for example, that Malaysia efforts to introduce enterprise unions following Japan's success with them have not quite provided the same result. The skills development fund system is successful in Singapore because it is part of an institutional context where several different institutions and practices work together to increase workforce skills, and it is difficult to ascribe responsibility to only one institution out of many. Besides, the factors that have caused success here may not quite cause the same success elsewhere.

However, there is much to learn herein terms of principles that will be of use to other nations whose economic development strategies are similar to that of Singapore, namely, moving from low cost exports driven by foreign investment to higher technology intensive exports. In particular, the principle of a close fit between economic development planning and workforce skills would be a necessary condition for most Asian economies. Most economies in Asia have some form of economic planning, done by the Finance or economics ministry, but the human resource future is the province of the HR or education ministries or government departments, and there is little coordination across these three Ministries or departments. Investing one authority with responsibility for both economic development and HR planning brings about a more tightly coupled "fit". This is an important lesson. Second, for those nations that depend heavily on foreign investment of economic development, the EDB's model of technology transfer has clear relevance. Third, it must be realized that not all government cultures are similar to that of Singapore's government culture, and hence, other countries may be wise in subcontracting some of the administrative operations to the private sector in new forms of public-private partnerships. In particular, one lesson is that the collaboration between the private and public sectors could be used to deliver other aspects of workforce preparedness, such as active labor market policies in other Asian nations. The key challenge for other nations is to take these principles, but then 
design appropriate institutions for the realization of these objectives.

Finally it is important to view this study as being exploratory, as it has several major limitations. We have the international acclaim and recognition that Singapore has gained as the best indicator of the skills development system's success, although we have not specifically looked at objective data in Singapore to make that claim. Second, we have not articulated a research strategy that will allow us to answer the crucial question of the relative importance of different factors in the success of the system, a necessary step to make a real resolution to the debate on the role of government in improving workforce skills. There is an urgent need to design an evaluation system to look at Singapore's success. Yet, there is value in this descriptive account, as it provides a basis from which specific hypotheses can be drawn. 


\section{References}

Azariadis, C and Drazen, A. (1991). Threshold Externalities in Economic Development. Quaterly Journal of Economics, 105, 501-26.

Barro, R.J.. (1997).Determinants of Economic Growth : A Cross-country Empirical Study. Cambridge, MA : The MIT Press

Becker, G. (1967). Human Capital and Personal Distribution of Income: An Analytical Approach. Ann Arbor: University of Michigan, Woytinsky Lecture. Republished in Gary S. Becker, Human Capital, New York: NBER, 1975.

Behrman, J. (1997). Simple Analytical Considerations for Skill development in for International Competitiveness. In Godfrey, M (ed). Skills Development for International Competitiveness. Cheltenham, UK: Edward Elgar

Bercuson, K. (1995). Singapore: A Case Study in Rapid Development. Washington, DC : International Monetary Fund, 1995.

Cheah, H.B. 91997). Can Governments Engineer the Transition from Cheap Labour to Skillbased Competitiveness? The Case of Singapore. . In Godfrey, M (ed). Skills Development for International Competitiveness. Cheltenham, UK: Edward Elgar

Chua, Rodney and Sarosh Kuruvilla (1997). How do Nations Upgrade Skills: The Singapore Case. Working Paper. The Aarhus School of Business, 1997

Edwards. C. (1997). State Failure or Market Failure? The Ten Steps to a Levy/Grant System. In In Godfrey, M (ed). Skills Development for International Competitiveness. Cheltenham, UK: Edward Elgar

FEER, (1996). Far Eastern Economic Review, November $14^{\text {th, }} 1997$.

Godfrey, M. (1997). Introduction. In Godfrey, M (ed). Skills Development for International Competitiveness. Cheltenham, UK: Edward Elgar

Hiers, W. and Arudsothy, P. 1999. From Ostensible Voluntarism to Interventionism in Malaysian Industrial Relations: The Colonial experience as an Important Variable. In S. Kuruvilla and B. Mundell (Eds.), The Institutionalization of Industrial Relations in Developing Economies. Stamford, CT: Jai Press.

Huff, W.G. (1994). The Economic Growth of Singapore: Trade and Development in the Twentieth Century. Cambridge: Cambridge University Press.

Koike, K.(1996). Globalization, Competitiveness and Workers Skills. Proceedings of the regional Meeting of the Asian Industrial Relations Association, Taipei, Taiwan, September 1996 
Kuruvilla, S. (1996) Industrialization Strategies and National Industrial Relations Policy in Southeast Asia: Singapore, Malaysia, Philippines, and India. Industrial and Labor Relations Review, 1996.Vol.

Kuruvilla, S. (1997). Globalization and Employment Relations: A Framework for Research. 1997 ILO EASTMAT: Bangkok.

Lewis. A.W. (1954). Economic Development with Unlimited Supplies of Labor, The Manchester School of Economic and Social Studies, 22, 139-91.

Lucas. R. E. (1988). On the Mechanics of Economic Development. Journal of Monetary Economics, 21, 3-42.

Pang, E.F. (1982). Education, Manpower, and Development in Singapore. Singapore University Press, 1982.

Rodan, G. (1993). Singapore Changes Guard: Social, Political and Economic Directions in the 1990s. Melbourne: Longman Cheshire

Romer, P. (1986). Increasing Returns and Long Run Growth. Journal of Political Economy, 94, 1002-36.

Schein. E. H. (1996). Strategic pragmatism : the culture of Singapore's Economic Development Board Cambridge, Mass. : MIT Press, 1996.

Singh, A. (1990) The Lost Decade: The Economic Crisis of the Third World in the 1980s. How the North caused the South's Crisis. Contention: Debates in Society, Culture, and Science, 103,136-168.

Skills Development Fund (1996). Annual Report. Presented to Parliament, September, 1996.

Solow, R. (1956). A Contribution to the Theory of Economic Growth. Quarterly Journal of Economics, 70, 65-94.

Soon, T. W. (1993). Education and Human Resource Development. In Low, L. Toh, M. H., Soon, T. W., Tan, K. Y, and Hughes, H. (1993). Challenge and Response - Thirty Years of the Economic Development Board. Times Academic Press: Singapore.

Stokey, N. (1991). Human Capital, product Quality and Growth. Quarterly Journal of Economics, 106, 587-616.

Wilkinson, B. (1994). Labor and Industry in the Asia Pacific. Walter de Gruyter: New York.

Vente, R.E. \& Chow, K.B. (1984). Education and training for industrial development in Singapore and other ASEAN countries: The role of private corporations, foreign aid, and 
regional cooperation: Baden-Baden: Nomos Verlagsgesellschaft and Singapore: Maruzen Asia Vogel, E. (1991). The Four Little Dragons. Harvard. .

Wood. A. (1994). Skill, land, and Trade: A Simple Analytic Framework. Working Paper no. 1, Brighton, Sussex: Institute for Development Studies.

World Bank (1993). The East Asian Miracle: Economic Growth and Public Policy, New York: Oxford University Press. 


\section{Appendix 1: ITE Courses}

\section{a. Worker General Education:}

The Basic Education for Skills Training (BEST) and the Worker Improvement through Secondary Education (WISE) are two national worker education programs offered by the ITE. BEST was introduced in 1983, and its purpose is to upgrade the English language and Math skills of workers up to the Primary Six level. WISE was introduced in 1987 with the motive of further upgrading the English and Math skills of workers up to the Secondary 4 Normal Level. These two programs are meant for those who some reason or other (typically the older generation who already passed schooling age when Singapore started its education reform plans after independence) missed their basic education opportunity during their early years. The programs serve to provide this group with the basics necessary for the many upgrading and retraining programs that Singapore has. The program is flexible in that they are administered during office hours, evenings and/or weekends.

Continuing Education (CE) programs at varying levels from Secondary 1 up to GCE "A" Levels (Junior College Level) are also available to provide workers with the chance to attain even higher levels of education. It is again very flexible in its schedule in that it can be taken part-time or during the weekends (Brief on the ITE).

\section{b. $\quad$ Worker Skill Training:}

The programs here also serve to give poorly educated and low skilled workers the basic foundation upon which they can acquire new and higher skills. The ITE has three schemes under this, namely MOST, TIME, and ACTS, and a description of each is as follows: (Brief on the ITE)

\section{Modular Skills Training (MOST)}

This was launched in 1986, and it offers a range of 128 skill training modules which will lead to certification at NTC-2, NTC-3, and Certificate of Competency (CoC) levels. It is meant to upgrade people who did not complete high school so that they can acquire new and higher level skills (Chow, Phoon, \& Law, 1996). This can be self, company or union sponsored financially. It is conducted in the evenings or weekends in order to avoid work disruption, and to date it has benefited about 46,700 workers. (*To date is Jan 1996).

\section{Training Initiative for Mature Employees (TIME)}

This was launched in 1991 targeted at upgrading needs of workers above 40 years old as this group has been identified as the most vulnerable group to changes in industry trends and technology. It has an open-entry system, is offered in four languages (this is to permit workers who are illiterate in English to undertake skill training), and workers can attend TIME courses on company's time. Again, this can be self, company or union sponsored financially. To date, 
1,610 workers have benefited from it.

\section{Adult Co-operative Training Scheme (ACTS)}

This was launched in 1992 targeted at lowly skilled and poorly educated workers between 20-40 years of age to acquire more skills via apprenticeship type of training (Consisting of on- and off-the-job training. Trainees here have to be fully sponsored by their employers, and to date, 550 workers have benefited.

\section{c. Industry-Based Training (IBT):}

With ITE's approval, companies or industry associations possessing the requisite infrastructure and expertise can set up training centers conducting skill specific training leading to ITE certification. There are currently 60 ITE approved training centers and since 1990, 6,420 workers have been trained under this scheme (Brief on the ITE).

\section{d. $\quad$ Customized Skills Training:}

The ITE also administer skill training programs that are tailored to the specific needs of companies. Till now, it has conducted 333 courses for 492 companies benefiting some 5,500 workers .

\section{e. $\quad$ Certified OJT Training Center (COJTC) Scheme:}

This was launched in April 1994 to encourage companies with a commitment to training and have the proper infrastructure to put their workers through OJT. Companies meeting the requests can implement customized OJT programs for their workers, who upon completion would receive OJT certificates. These certificates would be recognized by ITE, and can be used for gaining entry into ITE's NTC courses. To date, 201 companies have been registered and 16,000 workers have received skills training under the COJTC Scheme. ITE hopes to register 500 companies in this scheme by the year 2000 .

\section{First Industry-Wide On-the-Job Training (OJT) Program for the Process Industry:}

. The program was initiated by 6 major oil companies in October 1995, namely DuPont, Esso, Mobil, Shell, Singapore Petrochemical Complex, and the Singapore Refining Company, and 5 government agencies, namely Construction Industry Training Institute (CITI), EDB, ITE, NPB, and the Ministry of Labor. This is to train workers who perform specialized job functions and who do not need broad-based technical training. Over the next 5 years, over 5000 workers from 60 contractor companies would be trained under structured OJT. The 60 companies are also expected to set up in-house Certified On-the-Job Training Centers (COJTCs) that have to be 
approved by the ITE. Typically, ITE would give COJTC status to companies with high quality OJT practices and programs. As for companies failing to meet the requisites, ITE even offers to train the companies= trainers so that the company can too acquire the COJTC status. Workers who attain the Certificate of Competency from these structured OJTs can proceed to take up relevant ITE courses (Quality Workforce, Dec 95/Jan 96, Issue 24, ITE). 
Appendix 2. National Productivity Board Programs

Fast Forward:

This offers workers having family and work commitments with flexible training programs. It also accommodates workers who have little access to conventional training centers because of the lack of time or formal qualifications (Chow, Phoon, \& Law, 1996).

\section{On-the-Job Training Program:}

With the help of Seiko Instruments of Japan, this program assist companies in developing and implementing on-the-job training and in-company skills training (Chow, Phoon, \& Law, 199_).

\section{Information Technology Program for Office Workers:}

Known as IT Power, this is a 56-hour nationally driven program jointly developed by the NPB, SDF, IBM, National Computer Board (NCB), and the Singapore Telecom. It serves to give office workers a total perspective on information technology (including IT concepts and applications, and office automation), and to equip them with transferable keyboard skills. It is the only comprehensive generic program that covers word processing, spreadsheet, and database (Chow, Phoon, \& Law, 1996).

\section{NPB-Anderson Training Technology Center:}

This center was formed in 1990 via the joint-partnership between Anderson Consulting and NPB. It optimizes the use of technology to replace instructor led training programs. It promotes the used of TT-based training among companies in Singapore in the areas of Computer-Based Training (CBT), Interactive Videodisc Instruction (IVI), Digital Video Instruction (DVI), and Computer-Managed Instruction (CMI). It also helps companies convert their instructor-led training programs into TT-based programs (Chow, Phoon, \& Law, 1996).

\section{Increasing Training Opportunities (INTRO) Scheme:}

This provides incentives for companies to share their in-house expertise, facilities, and training programs with other companies (Chow, Phoon, \& Law, 1996).

\section{Training-Manager Program:}

This 40-hour program was jointly developed by the Civil Service Institute, the NPB Institute for Productivity Training, the Singapore Institute of Management, the Singapore Institute of Personnel Management, the Singapore National Employers Federation, and the Singapore Training and Development Association. The program's competency-based training 
provides managers and supervisors with the skills needed to identify training needs of their staff, and to conduct individual or group training programs (Chow, Phoon, \& Law, 1996). 


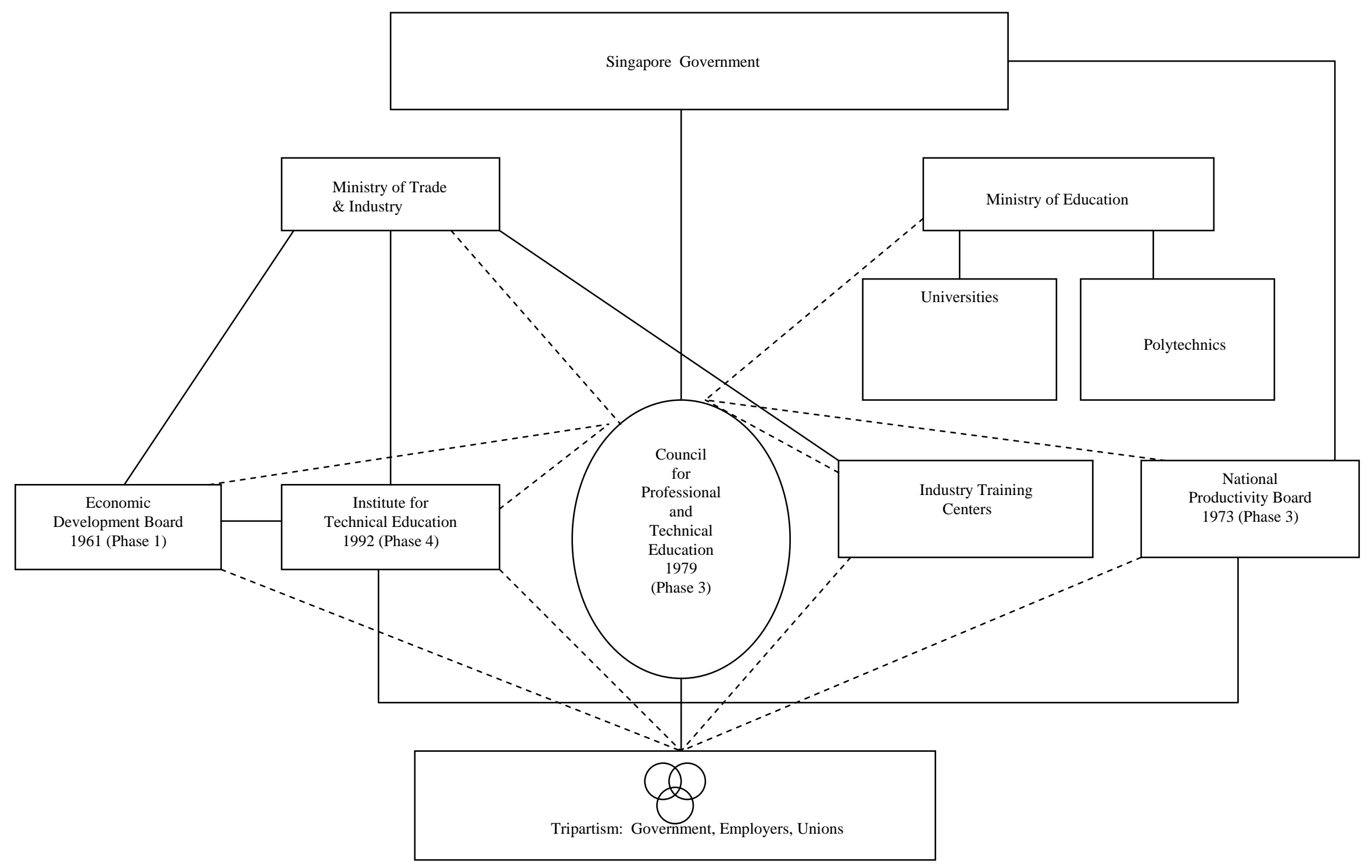




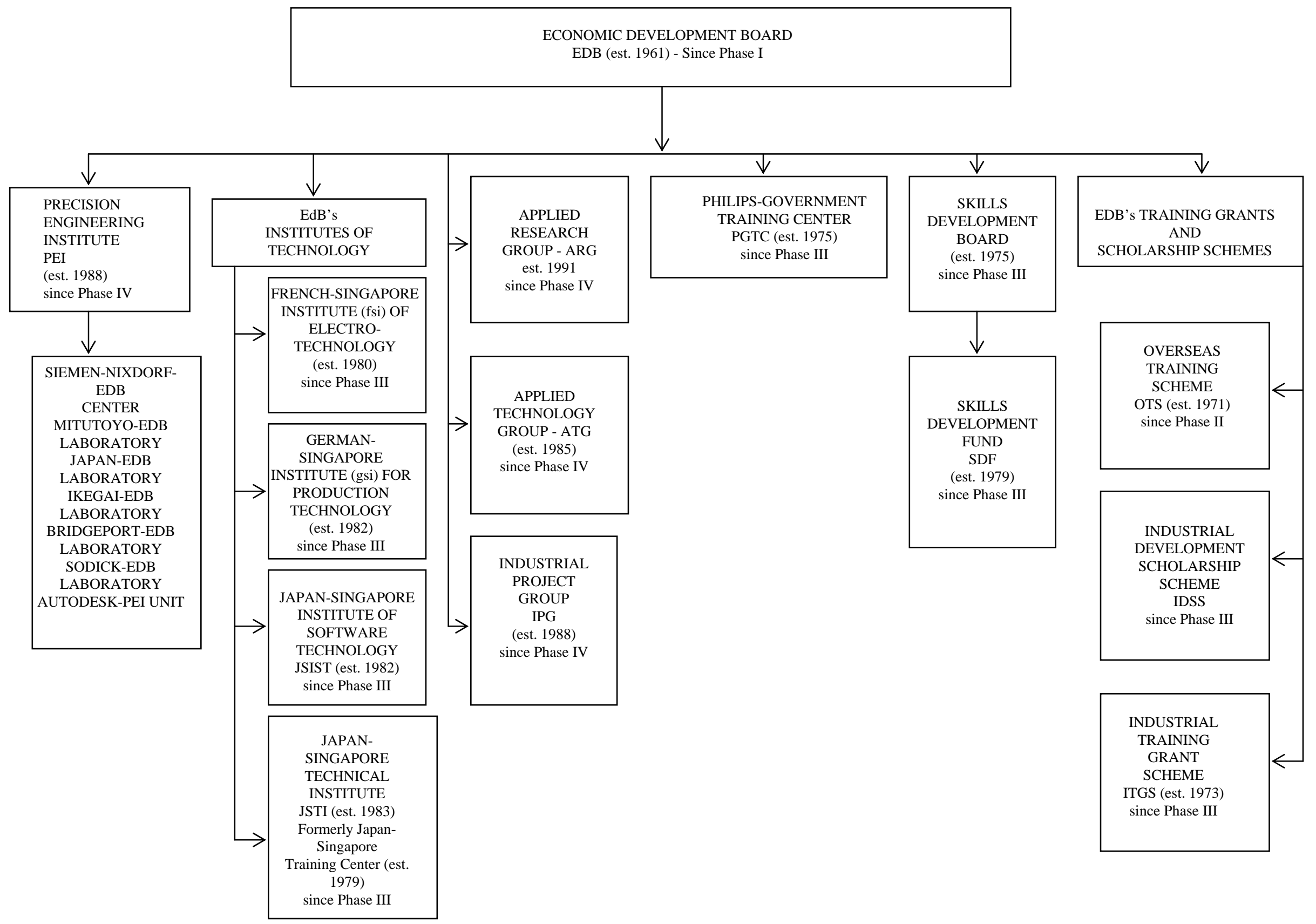




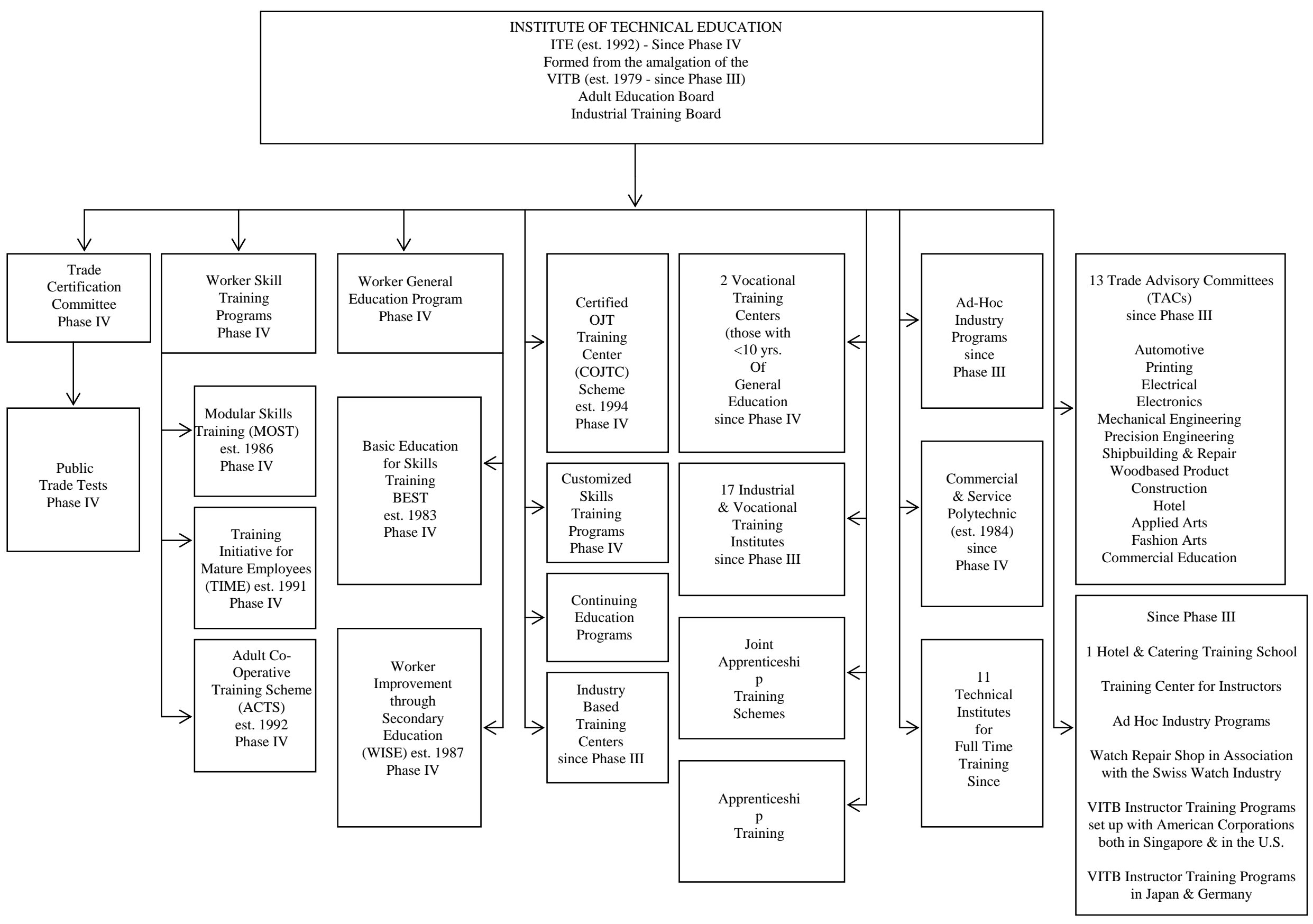




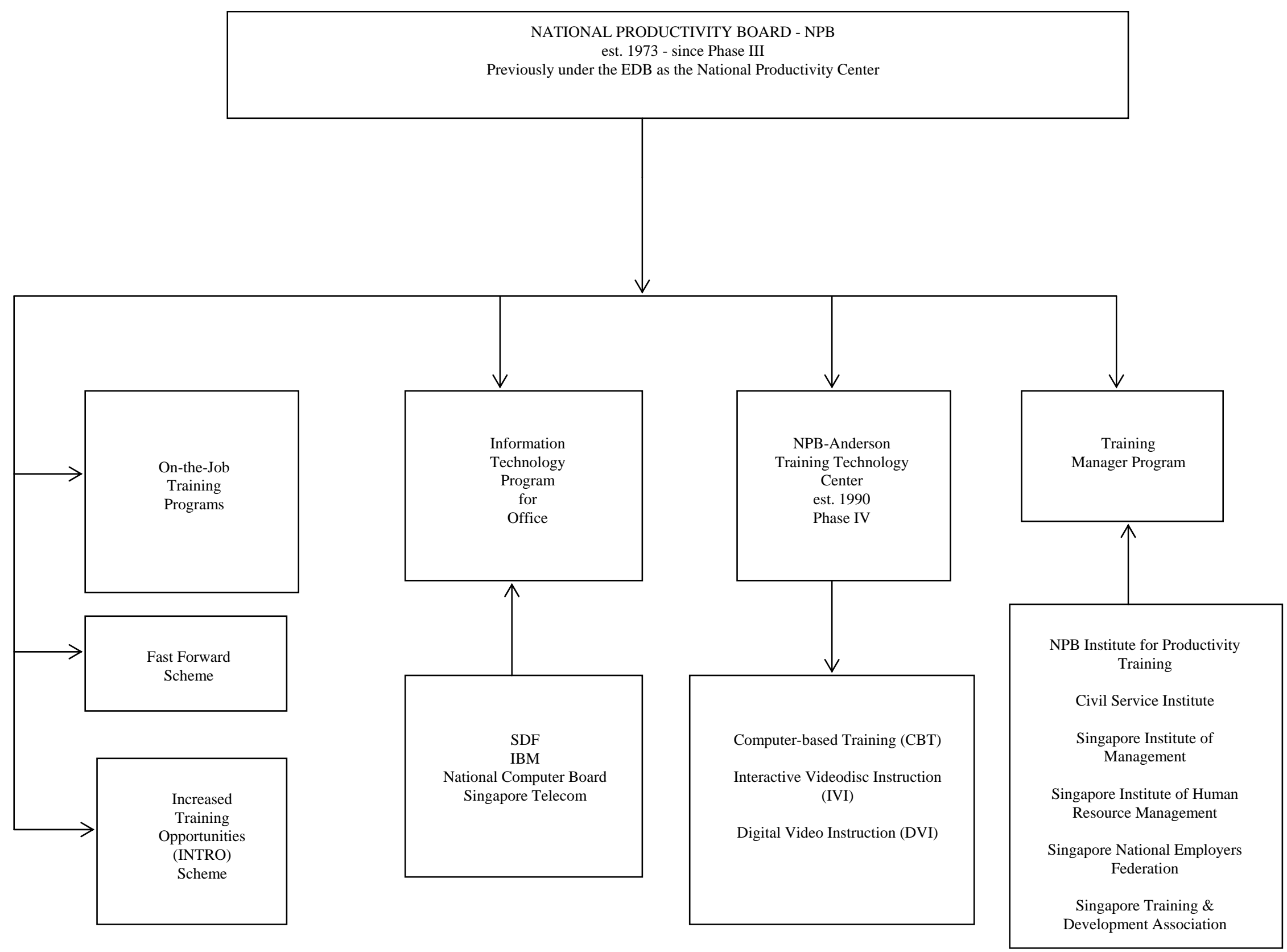



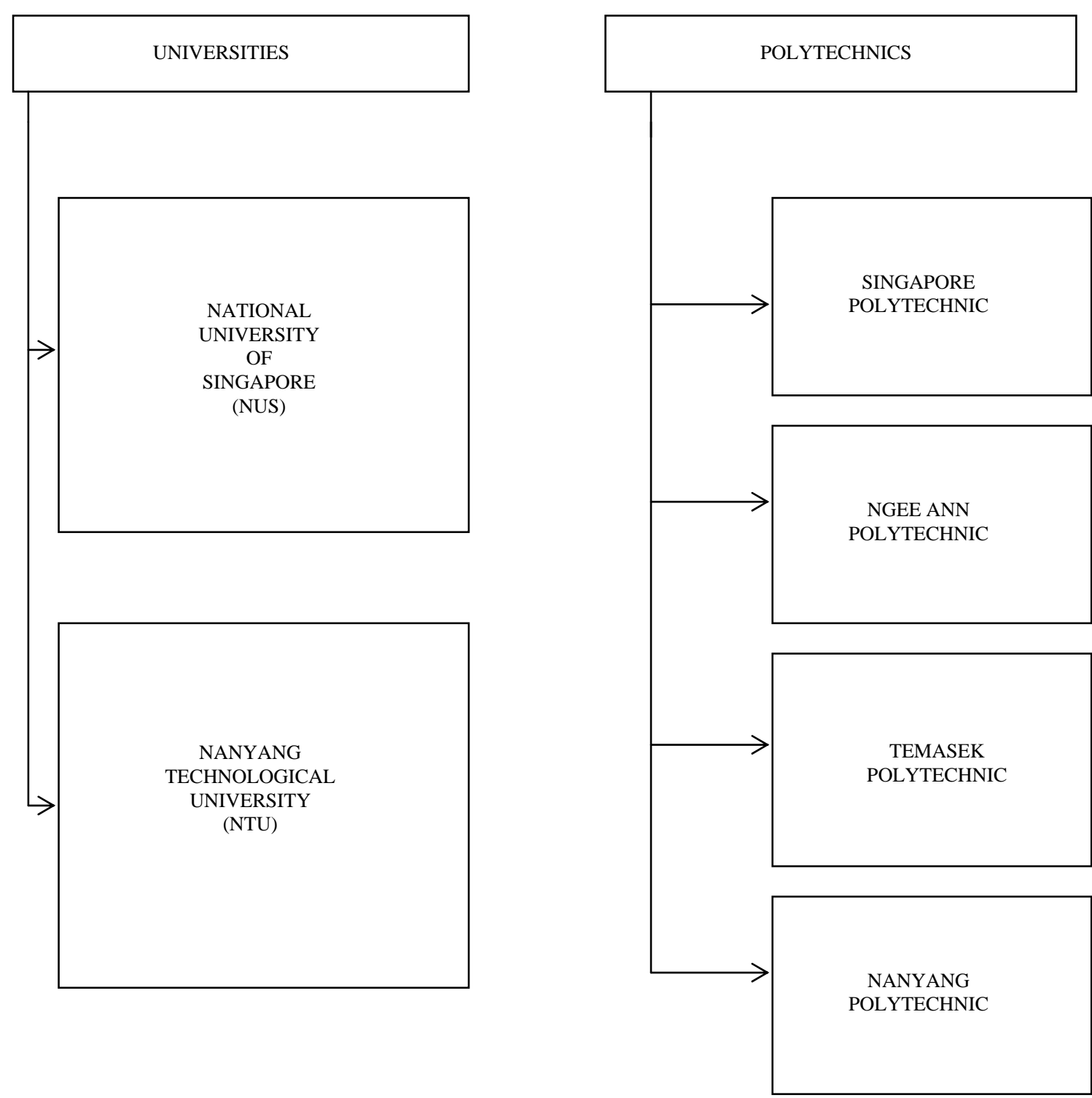

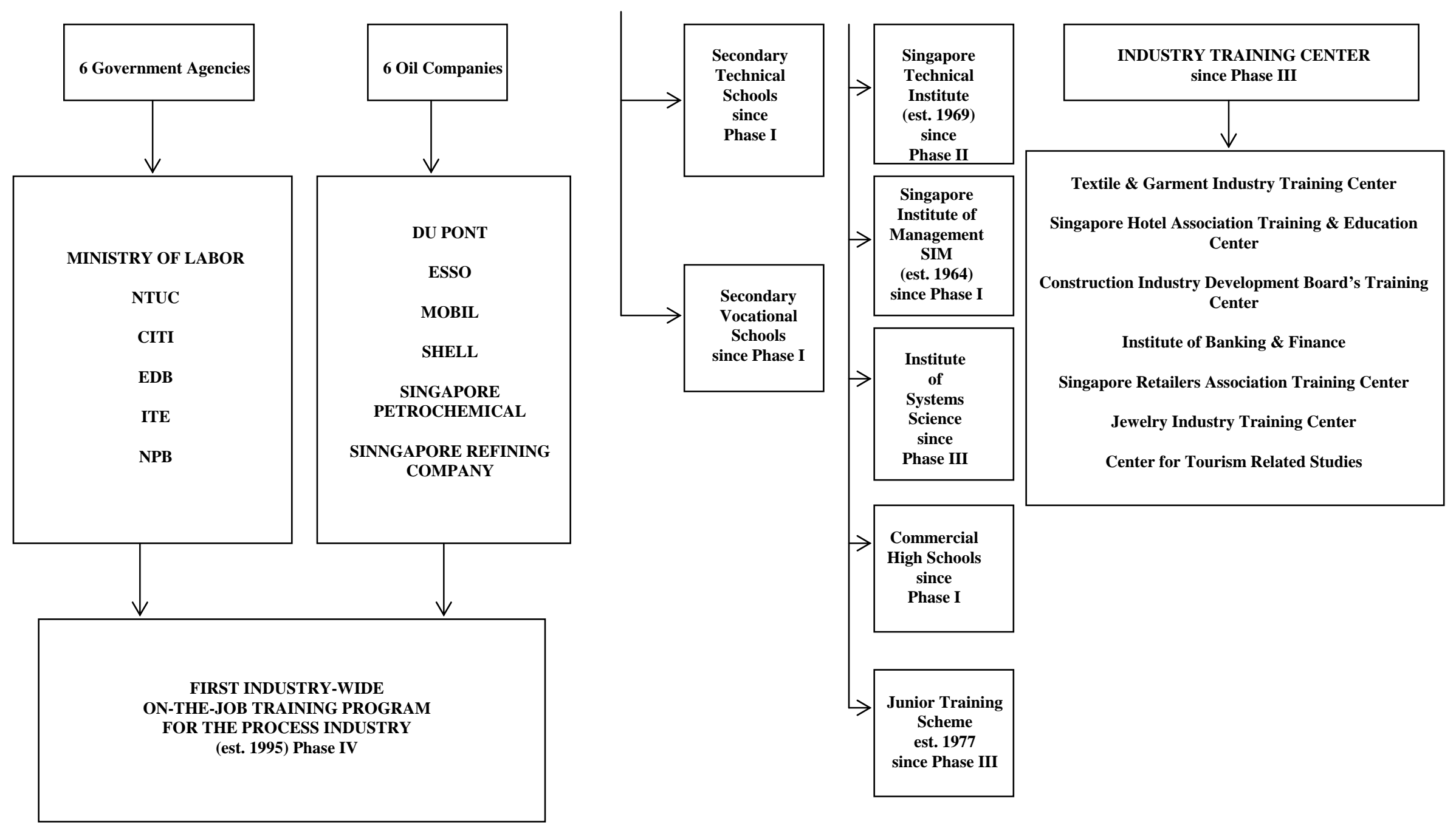


\section{Skills Development Fund}

The Skills Development Fund (SDF) provides incentive grants for training those in the workforce, those preparing to join the workforce, and those

re-entering the workforce. The grants are financed by collections from the Skills Development levy imposed on employers with workers earning $\$ 1,000$ or

less a month. The current levy rate is $1 \%$. Grants are awarded on the basis of a cost-sharing principle and the training must be relevant to the economic

development of Singapore. The amount of SDF grants that a company can obtain is not tied to the levy contribution.

\section{Eligibility Criteria}

All companies registered or incorporated in Singapore

Training is fully sponsored by companies

Workers who are Singaporeans, permanent residents of Singapore or three-year work permit / Q2 pass holders.

\section{Funding Mechanism}

The SDF's focus is worker* training. To support this focus, a set of funding guidelines has been established. The funding mechanism is as follows :

A flat rate of \$4 per trainee per hour for all broad-based training irrespective of whether training is conducted by company's own instructors or third party providers.

Course fee support for external training leading to national / industry-wide certification at 80\% subject to a maximum grant of $\$ 8$ per trainee per hour. For in-house training leading to national / industry-wide certification, enhanced incentive at $\$ 6$ per trainee per hour will be provided.

$80 \%$ of course fee support for external training in critical high-end / pioneering areas. For in-house training in these areas, enhanced incentive will be provided at $\$ 8$ per trainee per hour. A flat rate of $\$ 80$ per trainee per day for overseas training programmes conducted within Asia 
and flat rate of $\$ 120$ per trainee per day for overseas training outside Asia, subject to a maximum supportable training period of 6 weeks.

(* Workers are defined as employees who earn $\$ 1,000$ \& below and/or have 'A' level qualifications \& below)

What a Training Programme Must Have to Qualify for Support

Specific performance objectives

Schedule of training activities/lesson plans

Specified duration of training

Guided instruction, ie, conducted by qualified instructors

Test(s) to assess attainment of training objectives

Programmes that are Not Supported

Seminars and conferences designed to stimulate discussions and/or keep participants abreast of the latest trends in skills upgrading

Induction/orientation programmes, appreciation programmes or programmes specific to company procedures/policies

Training for spiritual, cultural and social enhancement, eg. religious studies and appreciation of music

Professional-training programmes, involving the upgrading of personnel such as doctors, lawyers, accountants and architects

Postgraduate training programmes, involving the pursuance of higher education leading to the award of an advanced diploma, graduate diploma, degree or post-degree qualification Senior management courses or top management programmes designed to give high level executives a wider business perspective

Attachment of engineers and senior managers to advance their skills and knowledge in existing or new work areas 
